\title{
Evidence for Genuine Bimetallic Frustrated Lewis Pair Activation of Dihydrogen with Gold(I)/Platinum(0) Systems
}

\author{
Nereida Hidalgo, Juan José Moreno, Marina Pérez-Jiménez, Celia Maya, Joaquín \\ López-Serrano*, Jesús Campos*
}

Instituto de Investigaciones Químicas (IIQ), Departamento de Química Inorgánica and Centro de Innovación en Química Avanzada (ORFEO-CINQA). Consejo Superior de Investigaciones Científicas (CSIC) and University of Sevilla.

Avenida Américo Vespucio 49, 41092 Sevilla (Spain).

E-mail: jesus.campos@iiq.csic.es ; joaquin.lopez@iiq.csic.es

\begin{abstract}
A joint experimental/computational effort to elucidate the mechanism of dihydrogen activation by a gold(I)/platinum(0) metal-only frustrated Lewis pairs is described herein. We have also investigated the drastic effects on $\mathrm{H}_{2}$ activation derived from subtle ligand modifications. The importance of the balance between bimetallic adduct formation and complete frustration has been interrogated, providing for the first time evidence for genuine metal-only FLP reactivity in solution. The origin of a strong inverse kinetic isotopic effect has also been clarified, offering further support for the proposed bimetallic FLP-type cleavage of dihydrogen.
\end{abstract}

\section{Introduction}

Frustrated Lewis pair (FLP) chemistry has become a continuously growing area of research owing to the ability of FLP systems to activate a wide range of small molecules. ${ }^{1}$ Moving from stoichiometric studies to catalysis has allowed the development of highly efficient hydrogenation processes that do not require the presence of a transition metal. ${ }^{2}$ Other related catalytic transformations such as hydrosilylation, ${ }^{3}$ hydroboration, ${ }^{4}$ hydroamination ${ }^{5}$ or dehydrogenation ${ }^{6}$ were soon disclosed for FLP systems and, more recently, the catalytic spectrum has spread with less conventional transformations, ${ }^{7}$ including $\mathrm{C}-\mathrm{H}$ functionalization reactions. In most cases, the individual constituents of FLPs are based on main group elements, typically the lighter ones, being phosphine-borane pairs the foremost and most paradigmatic examples. However, the inherent limitations of these elements in terms of redox reactivity have precluded the discovery of more sophisticated catalytic transformations on a regular basis. The incorporation of transition metals and their toolkit of elementary reactions into FLP systems emerged as a promising approach to extend their catalytic usefulness. ${ }^{8}$ To this regard, pioneering work from the groups of Wass ${ }^{9}$ and Erker $^{10}$ on zirconium-phosphine combinations was shortly followed by notable examples designed around a variety of metals, ${ }^{11}$ demonstrating the potential of transition metal frustrated Lewis pairs (TMFLPs) in small molecule activation and catalysis.

In this context, the design of frustrated systems in which the two components are based on transition metals became an obvious target. ${ }^{12}$ Encouraged by this idea, we recently described the first transition metal-only FLP (TMOFLP) by combining $\mathrm{Au}(\mathrm{I})$ and $\mathrm{Pt}(0)$ compounds as the acidic and basic counterparts respectively (Scheme 1). ${ }^{13}$ This metallic pair is active towards the activation of dihydrogen to yield a heterobimetallic dihydride (3a). As discussed later in more detail, we observed a drastically different reactivity for the TMOFLP and for the individual $\mathrm{Au}(\mathrm{I})$ and $\operatorname{Pt}(0)$ species, demonstrating the cooperative effect imparted by the two metals. 


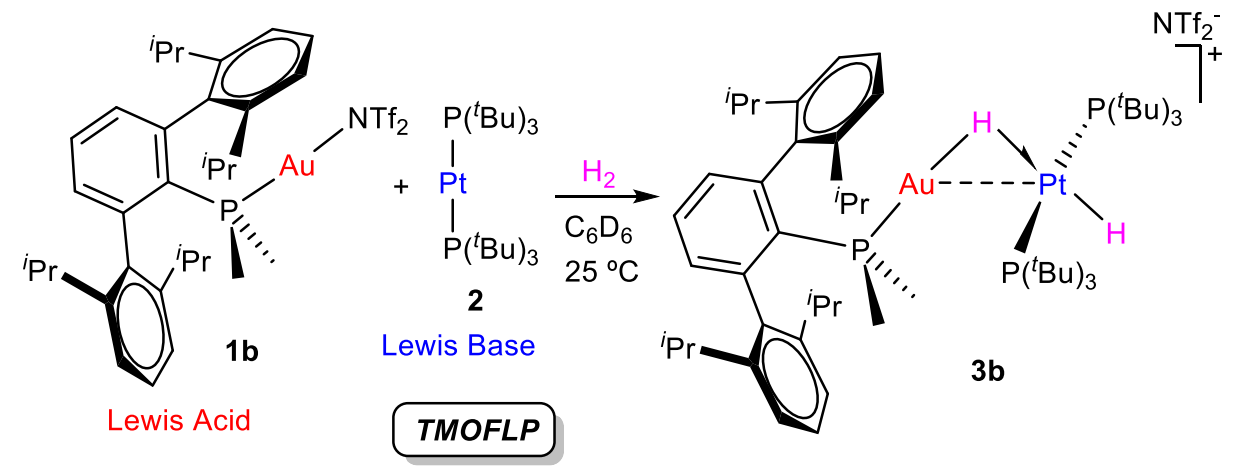

Scheme 1. Dihydrogen activation by a $\mathrm{Au}(\mathrm{I}) / \mathrm{Pt}(0)$ transition metal-only frustrated Lewis pair $(\mathrm{TMOFLP})\left(\mathrm{NTf}_{2}{ }^{-}\right.$(triflimide $\left.)=\left[\mathrm{N}\left(\mathrm{SO}_{2} \mathrm{CF}_{3}\right)_{2}\right]^{-}\right) . ;$Error! Marcador no definido.

The variety of potential chemical pathways to account for the $\mathrm{H}_{2}$ splitting depicted in Scheme 1 prevented us from providing a solid mechanistic picture during our preliminary investigations. ${ }^{13}$

In fact, the mechanisms by which TMFLPs operate remain underexplored compared to phosphine-borane and related main group designs. As an archetypical example, a vast amount of work has emerged to gain fundamental mechanistic understanding of the heterolytic cleavage of dihydrogen with traditional FLPs. ${ }^{14}$ Nonetheless, and despite being the simplest molecule to activate, the precise mechanism remains a matter of intense debate. ${ }^{15}$ Focusing on metalcontaining systems, most relevant information derives from the concept of metal-ligand cooperation, including prominent hydrogenation catalysts containing pendant Lewis acid or basic sites, whose reactivity resembles that of TMFLPs. ${ }^{8,16}$ In the same vein, the mechanistic knowledge regarding TMOFLPs is virtually nonexistent, albeit significant insights may be inferred from polar heterobimetallic complexes. ${ }^{17}$

An important aspect when studying mechanisms in FLP systems is the presence of acid-base interactions. Avoiding the formation of a dative bond between the Lewis acid and the Lewis base was once considered a sine qua non condition for FLP reactivity. However, a number of studies demonstrate that the so-called 'thermally induced FLPs', ${ }^{18}$ in which the resting state is a Lewis adduct, are competent for small molecule activation. ${ }^{19,20}$ In fact, these systems may even outperform their fully frustrated versions in catalytic applications. ${ }^{21}$ Thus, a precise control of the degree of frustration can be directly associated with catalytic efficiency (i.e. turnover frequency). ${ }^{22}$ With this in mind and in the light of the FLP-like reactivity exhibited by heterodinuclear complexes with an explicit M-M bond, ${ }^{17,23}$ we decided to investigate the effects derived from finely tuning the balance between metal-metal bond formation ${ }^{24}$ and complete metallic frustration in our gold(I)/platinum(0) system. To switch between the two extreme scenarios we have targeted herein three Lewis acidic gold complexes stabilized by terphenyl phosphines, $\mathrm{PR}_{2} \mathrm{Ar}$ ' $\left(\mathrm{R}=\right.$ alkyl; $\left.\mathrm{Ar}{ }^{\prime}=\mathrm{C}_{6} \mathrm{H}_{3}-2,6-\mathrm{Ar}_{2}\right)$, whose steric parameters were recently investigated by our group (Figure 1). ${ }^{25} \mathrm{We}$ provide a combined experimental and computational investigation that includes isolation and reactivity studies of competent intermediates, kinetic investigations and density functional theory (DFT) calculations with the aim of elucidating the mechanism of dihydrogen activation by $\mathrm{Au}(\mathrm{I}) / \mathrm{Pt}(0)$ TMOFLPs (Scheme 1), paying special attention to the effects of M-M interaction/frustration balance. 


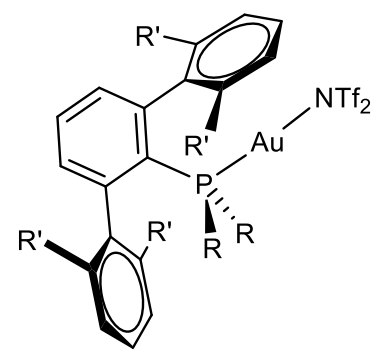

$$
\begin{aligned}
& \text { 1a: } R=M e ; R^{\prime}=M e \\
& \text { 1b: } R=M e ; R^{\prime}={ }^{i} P r \\
& \text { 1c: } R=C y p ; R^{\prime}=M e
\end{aligned}
$$

Figure 1. Lewis acidic gold complexes stabilized by terphenyl phosphines used in this work

$$
(\text { Cyp = cyclopentyl). }
$$

\section{Results and Discussion}

\section{Frustration versus Lewis adduct formation}

To modulate the equilibrium between the formation of a dative $\mathrm{Au} \leftarrow \mathrm{Pt}$ bond and complete bimetallic frustration we examined the interaction between $\operatorname{Pt}(0)$ compound 2 and $\mathrm{Au}(\mathrm{I})$ triflimide complexes 1a-c (Figure 1) bearing phosphines $\mathrm{PMe}_{2} \mathrm{Ar}^{\mathrm{Xyl2}}$ (1a), $\mathrm{PMe}_{2} \mathrm{Ar}^{\mathrm{Dipp} 2}$ (1) and $\mathrm{PCyp}_{2} \mathrm{Ar}^{\mathrm{Xyl2}}(\mathbf{1 c})(\mathrm{Cyp}=$ cyclopentyl). Compounds $\mathbf{1 a}$ and $\mathbf{1 c}$ were readily prepared by the same procedure previously reported for $\mathbf{1 b} .{ }^{26}$ The steric shielding provided by these phosphines follows the order $\mathrm{PCyp}_{2} \mathrm{Ar}^{\mathrm{Xy12}}>\mathrm{PMe}_{2} \mathrm{Ar}^{\mathrm{Dipp} 2}>\mathrm{PMe}_{2} \mathrm{Ar}^{\mathrm{Xy12}}$, 25 which has a direct impact on the reactivity of their gold triflimide complexes with compound $\mathbf{2}$, as will be discussed in detail in the following sections. For instance, when compound 1a, based on the less congested phosphine, is combined with an equimolar mixture of $\mathbf{2}$, the corresponding bimetallic Lewis adduct $\mathbf{4 a}$ is readily formed (Scheme 2). In contrast, compound $\mathbf{1 b}$ bearing the intermediate size phosphine $\left(\mathrm{PMe}_{2} \mathrm{Ar}^{\mathrm{Dipp} 2}\right)$, seems to be in equilibrium between adduct formation and monometallic fragments. This dynamic

\begin{tabular}{|c|c|c|c|}
\hline Solvent & $1 a+2 \rightarrow 4 a$ & $1 b+2 \rightarrow 4 b$ & $1 c+2 \rightarrow 4 c$ \\
\hline & \multicolumn{3}{|c|}{ Adduct formation (by NMR) } \\
\hline$C_{6} D_{6}$ & $\checkmark$ & $\mathbf{X}$ & $\mathbf{X}$ \\
\hline$C D_{2} \mathrm{Cl}_{2}$ & $\checkmark$ & Equilibrium & $\mathbf{X}$ \\
\hline \multirow[t]{2}{*}{$\mathrm{CD}_{2} \mathrm{Cl}_{2} / \mathrm{MeOH}$} & $\checkmark$ & $\checkmark$ & $\mathbf{X}$ \\
\hline & \multicolumn{3}{|c|}{$\Delta G^{o \text { solvent }}\left(D F T, \mathrm{kcal}^{\left.-\mathrm{mol}^{-1}\right)}\right.$} \\
\hline $\mathrm{C}_{6} \mathrm{H}_{6}$ & -2.5 & +1.7 & +17.5 \\
\hline $\mathrm{CH}_{2} \mathrm{Cl}_{2}$ & -7.2 & -2.4 & +10.8 \\
\hline
\end{tabular}
behavior is strongly affected by solvent, as previously investigated in detail for traditional FLP systems. ${ }^{27}$ Thus, in $\mathrm{C}_{6} \mathrm{D}_{6}$ solution, the ${ }^{1} \mathrm{H}$ and ${ }^{31} \mathrm{P}\left\{{ }^{1} \mathrm{H}\right\}$ NMR spectra of compounds

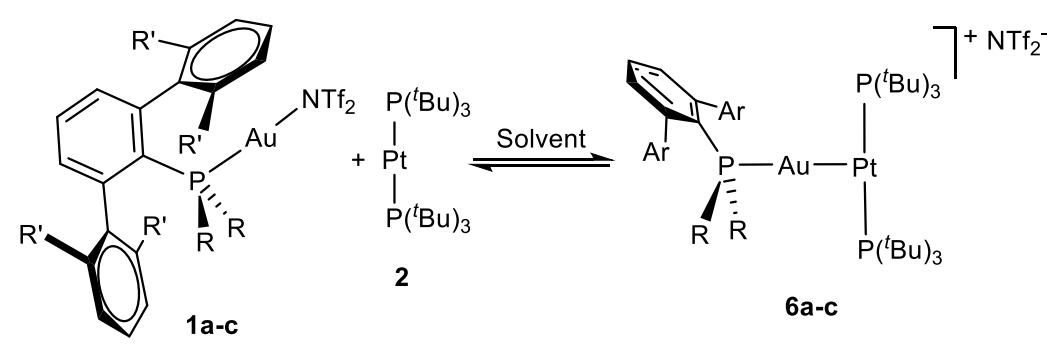

Scheme 2. Solution equilibria for adduct formation vs full frustration in $\mathrm{Au}(\mathrm{I}) / \mathrm{Pt}(0)$ bimetallic pairs as a function of ligand sterics and solvent conditions. 
$\mathbf{1 b}$ and 2 remained unaltered when mixed together, albeit using the more polar $\mathrm{CD}_{2} \mathrm{Cl}_{2}$ resulted in broadening of both of their ${ }^{31} \mathrm{P}\left\{{ }^{1} \mathrm{H}\right\}$ NMR signals, an observation that we attributed to the existence of the aforementioned equilibrium. ${ }^{13}$ Thus, Lewis adduct formation appears slightly favored under the more polar environment provided by $\mathrm{CD}_{2} \mathrm{Cl}_{2}$, as expected for the formation of two ionic species (4b and $\mathrm{NTf}_{2}{ }^{-}$). Moreover, we have now found that the addition of 10 equivalents of methanol results in rapid formation of $\mathbf{4} \mathbf{b}$. This result parallels with the recently described reactivity of the $\mathbf{4 b}: \mathbf{2}$ pair with germanium dichloride, which also leads to the formation of $\mathbf{4 b},{ }^{28}$ suggesting that the role of methanol may be facilitating triflimide solvation, promoting

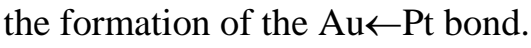

Formation of the unsupported heterobimetallic compound $\mathbf{4 b}$ was confirmed on the basis of ${ }^{1} \mathrm{H}$ and ${ }^{31} \mathrm{P}\left\{{ }^{1} \mathrm{H}\right\}$ NMR data. For the latter case, signals were recorded at $94.5\left({ }^{1} J_{\mathrm{PPt}}=3159,{ }^{3} J_{\mathrm{PP}}=2\right.$ $\mathrm{Hz})$ and $-34.2\left({ }^{1} J_{\mathrm{PPt}}=1984,{ }^{3} J_{\mathrm{PP}}=2 \mathrm{~Hz}\right) \mathrm{ppm}$, due to $\mathrm{P}(\mathrm{Bu})_{3}$ and $\mathrm{PMe}_{2} \mathrm{Ar}^{\text {Dipp2}}$, respectively. ${ }^{28}$ The analogous complex based on $\mathrm{PMe}_{2} \mathrm{Ar}^{\mathrm{Xyl2}}$ (4a) revealed similar ${ }^{1} \mathrm{H}$ and ${ }^{31} \mathrm{P}\left\{{ }^{1} \mathrm{H}\right\}$ NMR patterns, with characteristic ${ }^{31} \mathrm{P}\left\{{ }^{1} \mathrm{H}\right\}$ NMR resonances at $96.4\left({ }^{1} J_{\mathrm{PPt}}=3140,{ }^{3} J_{\mathrm{PP}}=3 \mathrm{~Hz}\right)$ and $-32.5\left({ }^{1} J_{\mathrm{PPt}}=\right.$ $\left.1933,{ }^{3} J_{\mathrm{PP}}=3 \mathrm{~Hz}\right) \mathrm{ppm}$. As in compound $\mathbf{4 b}$, the resonance due to the terphenyl phosphine appears highly shifted to lower frequencies with respect to its gold precursor $\mathbf{1 a}(\delta=-7.0 \mathrm{ppm})$. The molecular formulation of $\mathbf{4 a}$ was further validated by single crystal X-ray diffraction analysis (Figure 2), evincing a distorted T-shaped coordination at the platinum center. The P-Pt-P angle of $169.97(3)^{\circ}$ and $\mathrm{Au}-\mathrm{Pt}$ bond distance of $2.561(1) \AA$ are slightly widened and shortened, respectively, compared to $4 \mathbf{b}\left(\mathrm{P}-\mathrm{Pt}-\mathrm{P}=167.59(5)^{\circ} ; \mathrm{d}_{\mathrm{AuPt}}=2.575(1) \AA\right),{ }^{28}$ as expected for the smaller xylyl-based terphenyl substituent on the phosphine.

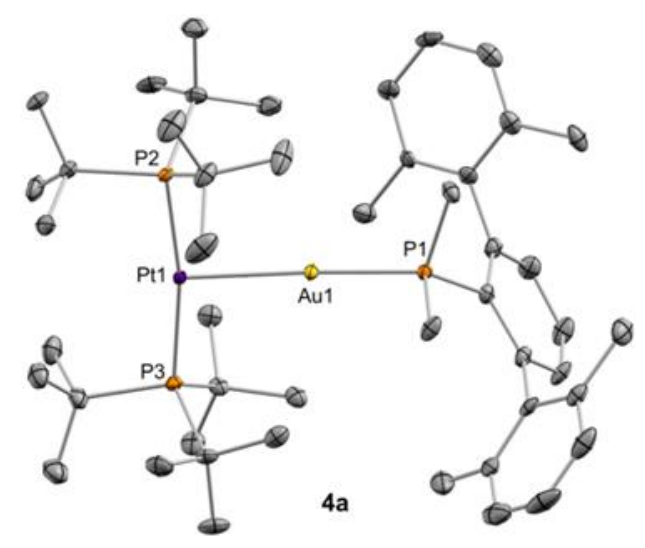

Figure 2. ORTEP diagram of compound 4a; for the sake of clarity hydrogen atoms and triflimide anion are excluded, while thermal ellipsoids are set at $50 \%$ probability.

Conversely, the analogous reaction based on 1c does not provide any spectroscopic sign for the formation of a new $\mathrm{Au} \leftarrow \mathrm{Pt}$ dative bond even under more forcing conditions (up to $80{ }^{\circ} \mathrm{C}$ with 100 equiv. of methanol). This contrasts with previous examples based on related $\left[\mathrm{Pt}(0)\left(\mathrm{PR}_{3}\right)\right]_{2}$ species, which in all cases led to the formation of metal-only Lewis pairs. ${ }^{29}$ Interestingly, while combining $\mathbf{1 a}$ or $\mathbf{1 b}$ with $\mathrm{Pt}(0)$ precursor $\mathbf{2}$ results in a distinct bright yellow color of the resulting solutions, the addition of $\mathbf{1 c}$ over benzene or chlorinated solutions of $\mathbf{2}$ did not alter the colorless appearance of the mixture, which we attribute to the absence of adduct $\mathbf{4 c}$. Thus, the steric pressure exerted by the two cyclopentyl substituents in $\mathrm{PCyp}_{2} \mathrm{Ar}^{\mathrm{Xyl2}}$ is likely responsible for quenching bimetallic Lewis adduct formation, which suggests a fully frustrated nature. These findings are in perfect agreement with our DFT computational studies $(\omega \mathrm{B} 97 \mathrm{XD} / 6$ $31 \mathrm{G}(\mathrm{d}, \mathrm{p})$ [SDD], see Scheme 2), where the formation of the bimetallic adduct in $\mathrm{CH}_{2} \mathrm{Cl}_{2}$ (SMD model $)^{30}$ is clearly exergonic for the systems based on $\operatorname{PMe}_{2} \mathrm{Ar}^{\mathrm{Xyl}}\left(\Delta \mathrm{G}=-7.2 \mathrm{kcal} \cdot \mathrm{mol}^{-1}\right)$ and $\mathrm{PMe}_{2} \operatorname{Ar}^{\text {Dipp2 }}\left(\Delta \mathrm{G}=-2.4 \mathrm{kcal} \cdot \mathrm{mol}^{-1}\right)$, while for the latter the process turns to be endergonic when changing the solvent to benzene, as observed experimentally. In contrast, accessing compound $\mathbf{4 c}$ 
based on $\mathrm{PCyp}_{2} \mathrm{Ar}^{\mathrm{Xyl} 2}$ is endergonic with respect to the monometallic fragments even in $\mathrm{CH}_{2} \mathrm{Cl}_{2}$ $\left(10.8 \mathrm{kcal} \cdot \mathrm{mol}^{-1}\right)$ (see SI for details).

Altogether, we have in hand a bimetallic pair where the M-M interaction/frustration balance can be rationally tuned from expeditious $\mathrm{M}-\mathrm{M}$ dative bond formation in $\mathrm{PMe}_{2} \mathrm{Ar}^{\mathrm{Xyl2}}$ to complete frustration in $\mathrm{PCyp}_{2} \mathrm{Ar}^{\mathrm{Xy1} 2}$, through an intermediate and adjustable equilibrium situation in $\mathrm{PMe}_{2} \mathrm{Ar}^{\mathrm{Dipp} 2}$. The effects of controlling this balance on the bimetallic reactivity and selectivity towards dihydrogen activation are discussed in the following section.

\section{Dihydrogen activation}

The activation of dihydrogen has continuously been examined as the prime benchmark reaction to demonstrate FLP behavior in main group systems. Similarly, we have investigated the activation of the $\mathrm{H}-\mathrm{H}$ bond by TMOFLP $\mathbf{1 b}: 2$ to confirm its FLP-like reactivity. ${ }^{13}$ iError! Marcador no definido. We now extend these studies to the metal-only Lewis pair $\mathbf{4 a}$, as well as to the fully frustrated TMOFLP 1c:2, while providing a full mechanistic picture that highlights the relevance of $\mathrm{M} \cdots \mathrm{M}$ interactions. Although the $\mathrm{H}-\mathrm{H}$ bond in dihydrogen is somehow the simplest covalent bond, we observe quite different product speciation for the three investigated $\mathrm{Au}(\mathrm{I}) / \mathrm{Pt}(0)$ systems (Table 1), despite the fact that they only differ on the substituents of the terphenyl phosphine.

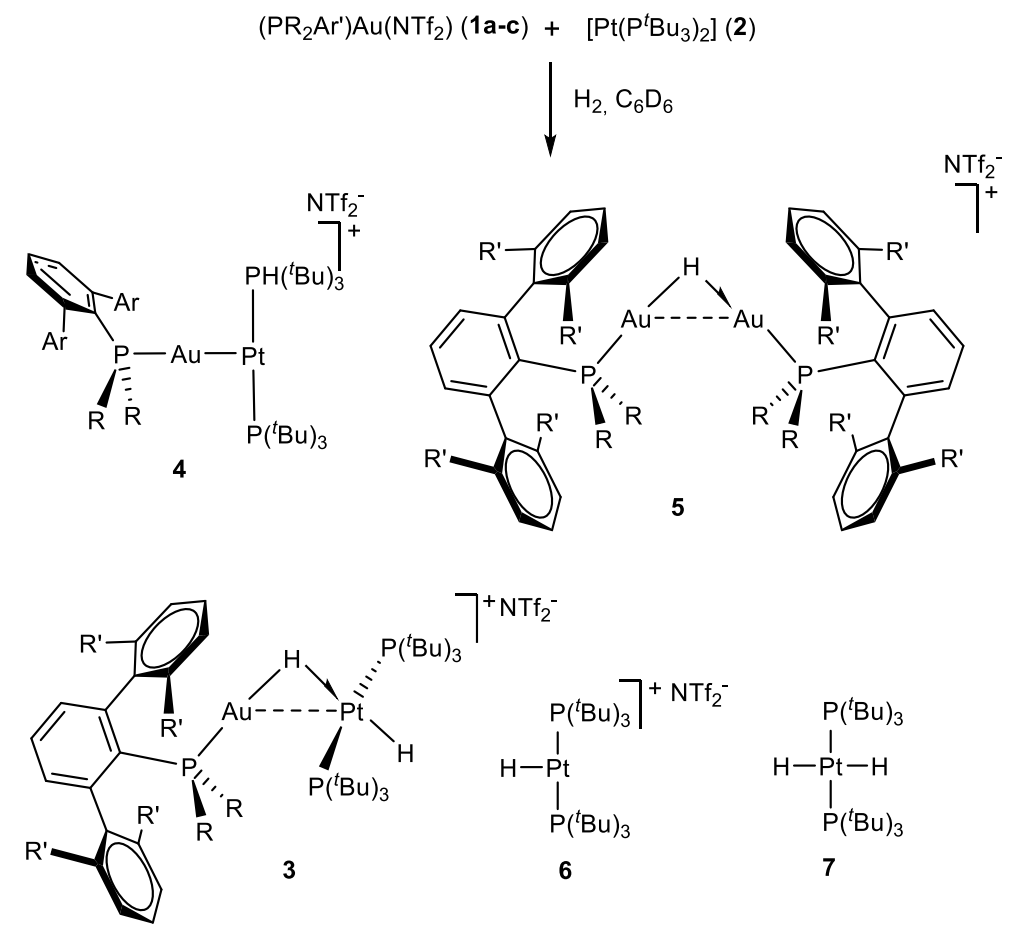

\begin{tabular}{|c|c|c|c|c|c|c|c|c|c|}
\hline \multirow{3}{*}{ Entry } & \multirow{3}{*}{ Gold } & \multirow{3}{*}{$\mathrm{t}$} & \multicolumn{7}{|c|}{ Product speciation (Yields (\%)) ${ }^{\mathrm{a}}$} \\
\hline & & & \multicolumn{2}{|c|}{$[\mathrm{Au}]$} & \multicolumn{2}{|c|}{$[\mathrm{Au}: \mathrm{Pt}]$} & \multicolumn{3}{|c|}{$[\mathrm{Pt}]$} \\
\hline & & & 1 & 5 & 3 & 4 & 2 & 6 & 7 \\
\hline 1 & \multirow{3}{*}{$1 a$} & $5 \mathrm{~min}$ & - & - & - & 100 & - & - & - \\
\hline 2 & & $12 \mathrm{~h}$ & - & - & 38 & 62 & - & - & - \\
\hline 3 & & $48 \mathrm{~h}$ & - & - & 99 & 1 & - & - & - \\
\hline 4 & \multirow{2}{*}{$1 b$} & $5 \mathrm{~min}$ & - & 99 & $<1$ & - & 50 & 50 & - \\
\hline 5 & & $12 \mathrm{~h}$ & - & $<1$ & $>95$ & - & - & $<1$ & - \\
\hline 6 & \multirow{2}{*}{ 1c } & $5 \min$ & 89 & 11 & - & - & 47 & 11 & 42 \\
\hline 7 & & $18 \mathrm{~h}$ & - & 95 & - & - & $8^{b}$ & $14^{\mathrm{b}}$ & $48^{b}$ \\
\hline
\end{tabular}


Table 1. Product speciation during FLP-like activation of $\mathrm{H}_{2}$ by 1:2 pairs

It is important to note that neither complex 2 nor gold precursors 1 evolved when their $\mathrm{C}_{6} \mathrm{D}_{6}$ solutions were exposed to dihydrogen $(1 \mathrm{bar})$ even under harsher reaction conditions $\left(80^{\circ} \mathrm{C}\right.$, up to 1 week) to those attempted with the metallic pairs. In stark contrast, TMOFLPs $\mathbf{1 b}: \mathbf{2}$ and 1c:2 readily react with $\mathrm{H}_{2}\left(1 \mathrm{bar}, 25{ }^{\circ} \mathrm{C}\right)$, with the former pair exhibiting faster $\mathrm{H}-\mathrm{H}$ cleavage. Complete consumption of $\mathbf{1 b}$ was observed by the time spectra were recorded rapidly after sample preparation $(<5 \mathrm{~min})$ to yield a 1:1:1 mixture of the hydride-bridged digold compound $\mathbf{5 b}$, platinum hydride $\left[\mathrm{Pt}\left(\mathrm{P}^{t} \mathrm{Bu}_{3}\right)_{2}(\mathrm{H})\right]^{+}(\mathbf{6})^{31}$ and unreacted 2 (Table 1, entry 4). Low-temperature ${ }^{1} \mathrm{H}$ and ${ }^{31} \mathrm{P}\left\{{ }^{1} \mathrm{H}\right\}$ NMR monitoring revealed the extreme reactivity of TMOFLP $\mathbf{1 b}: \mathbf{2}$ towards $\mathrm{H}_{2}$, since $\mathrm{H}-\mathrm{H}$ cleavage is observed even at $-20{ }^{\circ} \mathrm{C}$, with a half-life for compound $\mathbf{1 b}$ of $c a .120 \mathrm{~min}$ at that temperature. The foregoing mixture evolved to the heterobimetallic dihydride $\mathbf{3 b}$ after 12 hours at $25^{\circ} \mathrm{C}$ as the only discernible product by NMR spectroscopy (entry 5).

Although proceeding at a lower rate, TMOFLP 1c:2 built on $\mathrm{PCyp}_{2} \mathrm{Ar}^{\mathrm{Xy} 12}$ exhibited smooth reactivity towards $\mathrm{H}_{2}$ even after short reaction times, with conversion of one tenth of $\mathbf{1 c}$ and more than half of 2 (entry 6) by the time NMR spectra were recorded ( $c a .5 \mathrm{~min}$ ). The formation of platinum dihydride $\mathbf{7},{ }^{32}$ which was not observed when combining $\mathbf{1 b}$ and $\mathbf{2}$, accounts for the dissimilar conversion rate of $\mathrm{Pt}(0)$ complex 2 compared to $\mathrm{Au}(\mathrm{I})$ species $1 \mathbf{c}$. This finding suggests an unconventional catalytic role of gold for the hydrogenation of $\mathbf{2}$ towards $7 .{ }^{33}$ We demonstrated this by exposing $\mathrm{C}_{6} \mathrm{D}_{6}$ solutions of 2 to $\mathrm{H}_{2}$ atmosphere $(0.5$ bar) under variable catalytic amounts of 1c (Scheme 3). Intriguingly, best yields for the hydrogenated product ( $c a .80 \%$ of 7 ) derived from using $10 \mathrm{~mol} \%$ of gold catalyst 1c, whereas increasing its amount to $30 \%$ had a detrimental effect (only $17 \%$ of 7 formed) under otherwise identical conditions. This may result from a complex series of solution equilibrium processes existing after FLP-like $\mathrm{H}-\mathrm{H}$ bond cleavage (see Scheme 4). For this system, the main gold containing species (ca. 95\%) in the long term (18 hours) is the hydride-bridged digold compound $\mathbf{5 c}$, while half of the platinum precursor was converted into dihydride 7 after that time, accompanied by smaller amounts (ca. $10 \%)$ of unreacted $\mathbf{2}$ and monohydride 6, along with other unidentified Pt-containing species (entry 7). No signals of a presumed heterobimetallic dihydride $\mathbf{3 c}$ were detected, likely due steric reasons on account of $\mathrm{PCyp}_{2} \mathrm{Ar}^{\mathrm{Xy12}}$.

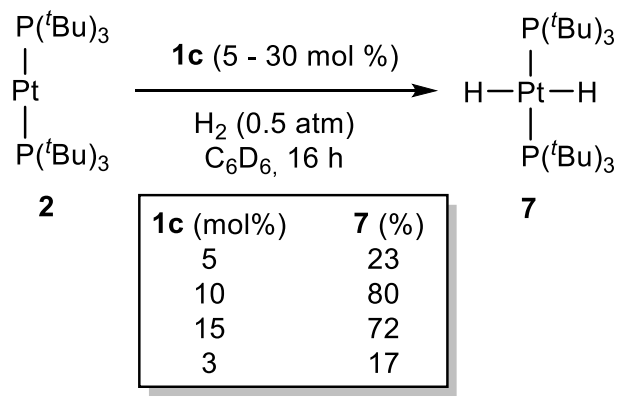

Scheme 3. Catalytic hydrogenation of $\mathbf{2}$ mediated by $\mathbf{1 c}$.

Product speciation is considerably simplified with the less hindered system (1a:2) based on $\mathrm{PMe}_{2} \mathrm{Ar}^{\mathrm{Xyl} 2}$, which immediately yielded the metal-only Lewis pair $\mathbf{4 a}$ even in the presence of dihydrogen. $\mathrm{H}-\mathrm{H}$ bond activation proceeds at a considerably slower pace, with full conversion to 3a reached after two days at $25{ }^{\circ} \mathrm{C}$ (entries 1-3), while no intermediates were detected by ${ }^{1} \mathrm{H}$ or ${ }^{31} \mathrm{P}\left\{{ }^{1} \mathrm{H}\right\}$ NMR methods. Overall, the rate of $\mathrm{H}-\mathrm{H}$ bond cleavage follows the trend $\mathbf{1 b}: 2$ $\left(\mathrm{PMe}_{2} \mathrm{Ar}^{\mathrm{Dipp} 2}\right)>\mathbf{1 c}: 2\left(\mathrm{PCyp}_{2} \mathrm{Ar}^{\mathrm{Xyl} 2}\right)>>\mathbf{1 a}: 2\left(\mathrm{PMe}_{2} \mathrm{Ar}^{\mathrm{Xyl}}\right)$. As discussed later in deeper detail, this trend supports the notion of a genuine FLP-type $\mathrm{H}-\mathrm{H}$ cleavage, since the existence of a $\mathrm{Au} \leftarrow \mathrm{Pt}$ dative bond (1a; $\mathrm{PMe}_{2} \mathrm{Ar}^{\mathrm{Xyl2}}$ ) handicaps $\mathrm{H}_{2}$ activation, while forcing complete frustration by steric 
clash (1c; $\mathrm{PCyp}_{2} \mathrm{Ar}^{\mathrm{Xy12}}$ ) somehow diminishes the rate of activation compared to the intermediate interaction/frustration situation found for the $\mathbf{1 b}: 2$ pair based on $\mathrm{PMe}_{2} \mathrm{Ar}^{\mathrm{Dipp} 2}$.
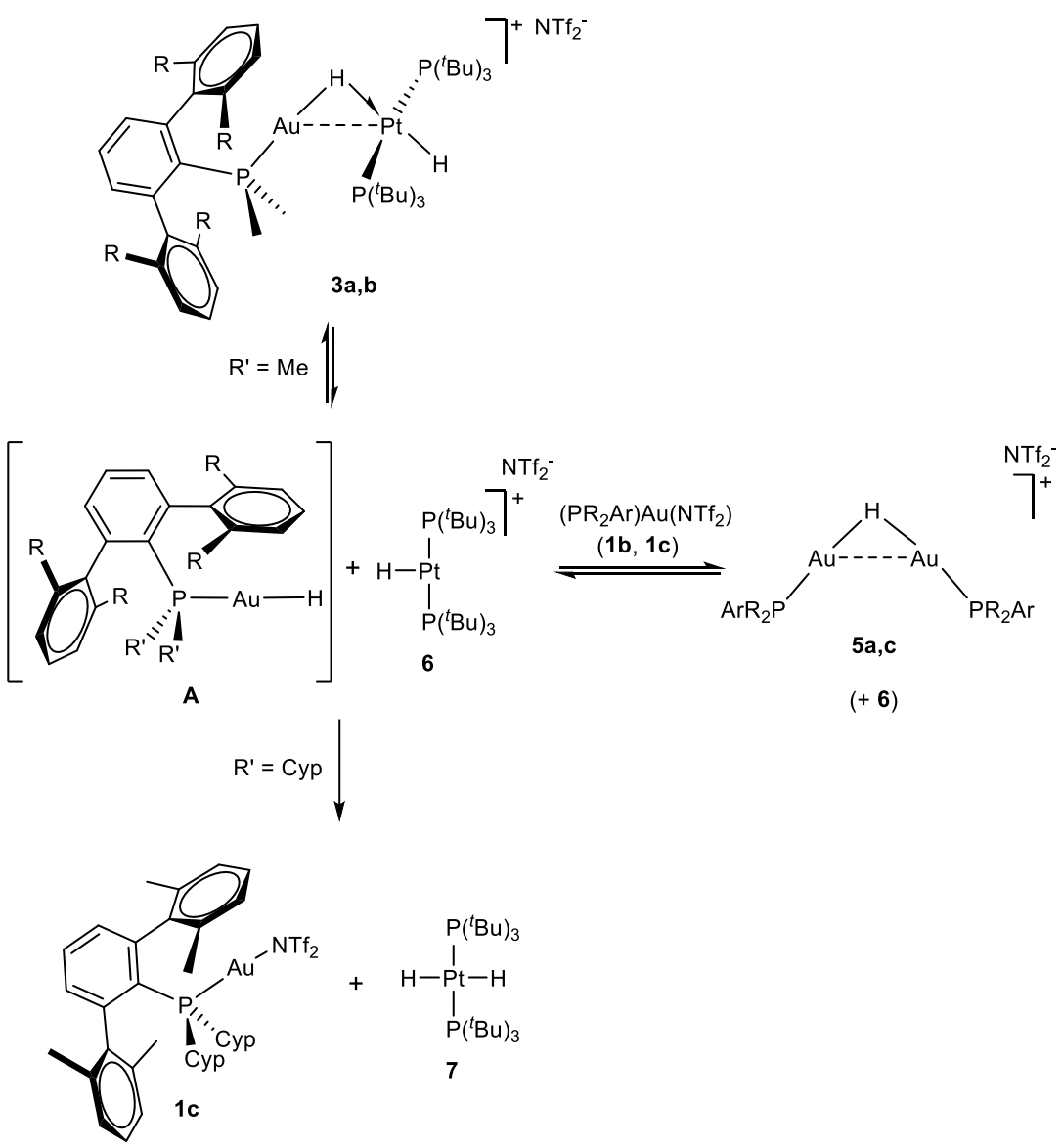

Scheme 4. Proposed reaction pathways taking place after H-H cleavage by 1:2 pairs.

As aforementioned, we assume metal speciation after $\mathrm{H}_{2}$ splitting to result from a series of equilibria that are likely controlled by steric reasons. We have not been able to spectroscopically observe a gold monohydride species A (Scheme 4) that would arise from heterolytic $\mathrm{H}-\mathrm{H}$ cleavage, since it seems to be rapidly trapped by still unreacted gold triflimide $\mathbf{1}$ to yield digold hydrides $\mathbf{5}$, as it also occurs when treating compounds 1 with $\mathrm{SiEt}_{3} \mathrm{H}$ (see Experimental Section). Nevertheless, in the case of the less hindered 1a, direct access to heterobimetallic dihydride 3a is kinetically favored. The reduced size of $\mathrm{PMe}_{2} \mathrm{Ar}^{\mathrm{Xyl2}}$ may facilitate the approach of platinum complex $\mathbf{6}$ to give the thermodynamic product, 3a. In turn, the reversible formation of compounds $\mathbf{5}$ would account for the slow formation $(c a .12 \mathrm{~h}$ ) of $\mathbf{3 b}$ by trapping the continuously liberated monohydride A (from $\mathbf{5 b}$ ) by $\mathbf{2}$. However, the more sterically congested system based on $\mathrm{PCyp}_{2} \mathrm{Ar}^{\mathrm{Xyl} 2}$ precludes the observation of $\mathbf{3 c}$, likely due to steric reasons. Thus, we hypothesize an alternative pathway involving hydride abstraction by cationic platinum $\mathbf{6}$ to produce $\mathbf{7}$ and generate gold triflimide 1c. This would explain the catalytic role of gold for the hydrogenation of $\operatorname{Pt}(0)$ 2. Overall, the prevalence of each of the interrelated reactions seems to be controlled by steric reasons and is responsible for the product speciation observed with the three investigated terphenyl phosphines.

The molecular formulation of compound 3a was ascertained by multinuclear NMR spectroscopy, where distinctive ${ }^{1} \mathrm{H}$ NMR resonances at $-1.75\left({ }^{2} J_{\mathrm{HP}}=110 \mathrm{~Hz},{ }^{1} J_{\mathrm{HPt}}=516 \mathrm{~Hz}\right)$ and $-10.39 \mathrm{ppm}$, due to the bridging and terminal hydride, respectively, were recorded. Both low-frequency signals where flanked by ${ }^{195} \mathrm{Pt}$ satellites with coupling constants of 516 and $1030 \mathrm{~Hz}$, respectively. Besides, ${ }^{195} \mathrm{Pt}$ satellites accompanying the corresponding ${ }^{31} \mathrm{P}\left\{{ }^{1} \mathrm{H}\right\}$ NMR signals at $91.5\left({ }^{1} J_{\mathrm{PPt}}=\right.$ 
$\left.2713 \mathrm{~Hz}, \mathrm{P}\left({ }^{t} \mathrm{Bu}\right)_{3}\right)$ and $5.7\left({ }^{2} J_{\mathrm{PPt}}=208 \mathrm{~Hz}, \mathrm{PMe}_{2} \mathrm{Ar}^{\mathrm{Xyl}}{ }^{2}\right)$ evinced the presence of a $\mathrm{Au} \cdots \mathrm{Pt}$ interaction in 3a. These data compared well with its related compound $\mathbf{3 b}\left(\delta_{1 \mathrm{H}}=-1.67\left({ }^{2} J_{\mathrm{HP}}=112\right.\right.$ $\left.\left.\mathrm{Hz},{ }^{1} J_{\mathrm{HPt}}=503 \mathrm{~Hz}\right),-11.39\left({ }^{1} J_{\mathrm{HPt}}=1053 \mathrm{~Hz}\right) ; \delta_{31 \mathrm{P}}=90.0\left({ }^{1} J_{\mathrm{PPt}}=2744 \mathrm{~Hz}\right), 7.2\left({ }^{2} J_{\mathrm{PPt}}=200 \mathrm{~Hz}\right)\right) .{ }^{13}$ With regards to compound $\mathbf{5 b}$, the main gold containing species for the $\mathrm{PMe}_{2} \mathrm{Ar}^{\mathrm{Dipp} 2}$ system after short periods of time (Table 1, entry 4), we previously assumed a digold hydride-bridged formulation. ${ }^{13}$ We made this statement exclusively based on NMR data, particularly on a distinctive ${ }^{1} \mathrm{H}$ NMR signal at $2.83 \mathrm{ppm}$ that appears as a triplet $\left({ }^{2} J_{\mathrm{HP}}=99.5 \mathrm{~Hz}\right)$ and was attributed to the bridging hydride. However, all attempts to isolate this compound in the past proved unsuccessful due to formation of $\left[\mathrm{Au}\left(\mathrm{PMe}_{2} \mathrm{Ar}^{\mathrm{Dipp} 2}\right)_{2}\right]^{+}$with concomitant release of hydrogen and appearance of gold nanoparticles $\left(t_{1 / 2}\right.$ at $\left.25{ }^{\circ} \mathrm{C} \approx 3 \mathrm{~h}\right)$. In stark contrast, the steric shrouding provided by $\mathrm{PCyp}_{2} \mathrm{Ar}^{\mathrm{Xyl2}}$ allowed us isolate the first stable compound of type $\left[\mathrm{Au}_{2}(\mu-\mathrm{H})\left(\mathrm{PR}_{3}\right)_{2}\right]^{+}$ (5c) authenticated by single-crystal X-ray diffraction (Figure 3). This compound was independently prepared by reacting $\mathbf{1 c}$ and $\mathrm{SiEt}_{3} \mathrm{H}$ (see Experimental Section). ${ }^{34} \mathrm{~A}$ short $\mathrm{Au}-\mathrm{Au}$ distance of $2.748(1) \AA$ suggests the existence of a strong aurophilic interaction, ${ }^{35}$ being comparable to other hydride-bridged digold complexes (2.70-2.78 $\AA$ ). EError! Marcador no definido. ${ }^{\mathrm{b}, 36}$ In its ${ }^{1} \mathrm{H}$ NMR spectrum, the bridging hydride appears as a triplet at $4.78 \mathrm{ppm}$ and features a strong coupling with the ${ }^{31} \mathrm{P}$ nuclei $\left({ }^{2} J_{\mathrm{HP}}=90.9 \mathrm{~Hz}\right)$, comparable to $\mathbf{5 b}$ and to a related species based on $\mathrm{P}\left({ }^{t} \mathrm{Bu}\right)_{2}(o \text {-biphenyl })^{34 \mathrm{c}}$ and thus further supporting our prior formulation.

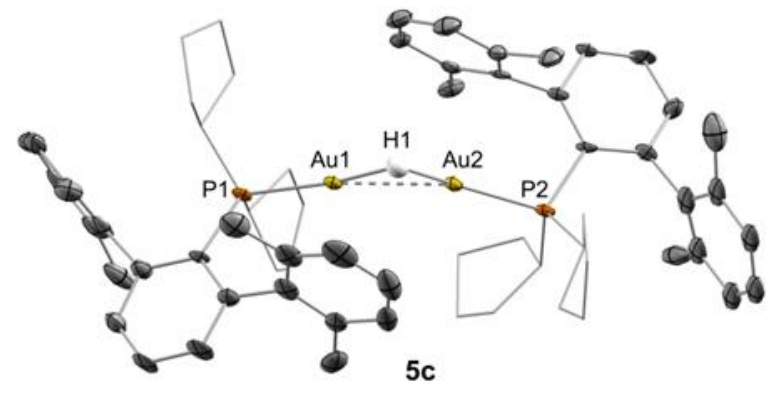

Figure 3. ORTEP diagram of compound $\mathbf{5 c}$; for the sake of clarity hydrogen atoms (except the gold hydride) and triflimide anion are excluded and cyclopentyl substituents have been represented in wireframe format, while thermal ellipsoids are set at $50 \%$ probability.

As discussed in the introduction, the mechanism of $\mathrm{H}-\mathrm{H}$ bond cleavage for a variety of cooperative systems has been extensively investigated. ${ }^{15,16}$ In the context of heterobimetallic designs, three main scenarios can be envisaged. Those are represented in Scheme 5 with regard to our $\mathrm{Au}(\mathrm{I}) / \mathrm{Pt}(0)$ pairs. In the first, dihydrogen is added across the $\mathrm{Au}-\mathrm{Pt}$ bond to yield two monometallic hydrides which, after rapid rearrangement, would lead to the final heterobimetallic dihydride 3 (Scheme 5a). Alternatively, the $\mathrm{H}-\mathrm{H}$ bond could be cleaved by the cooperative action of the two independent metallic fragments, that is, by a truly FLP-type mechanism (Scheme $5 b)$. As before, the resulting monohydrides could readily evolve towards $\mathbf{3}$. The third possible route involves the orthogonal reactivity of a metal fragment that initially activates the dihydrogen molecule and subsequently evolves to the final heterobimetallic compound in the presence of the second metal fragment (Scheme 5c). In principle, this mechanism may operate both in the presence or absence of a $\mathrm{Au}-\mathrm{Pt}$ bond. 


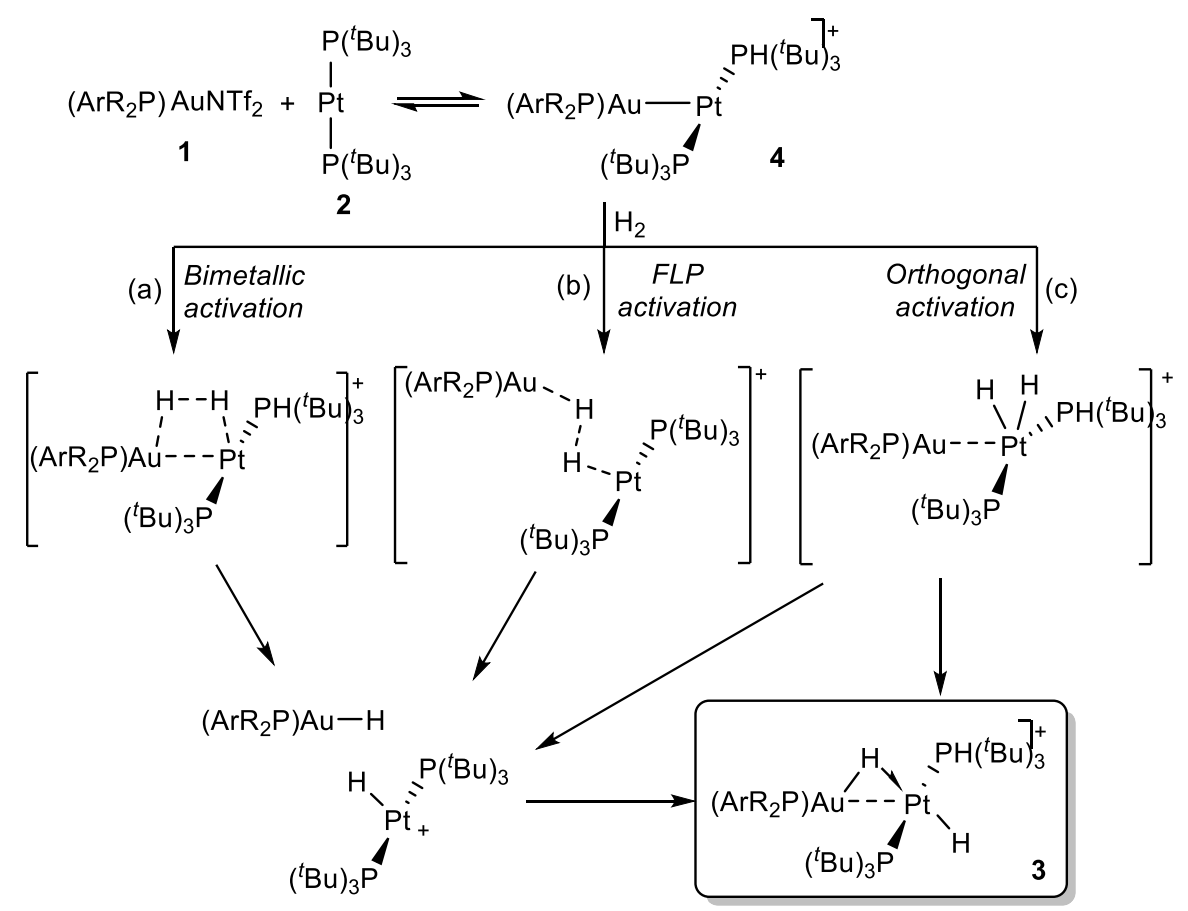

Scheme 5. Cooperative $\mathrm{H}_{2}$ activation involving (a) traditional bimetallic activation across a MM bond; (b) transition metal-only FLP activation and (c) orthogonal reactivity.

We had tentatively proposed a genuine FLP pathway as in Scheme $5 b$ for the pair $\mathbf{1 b}: \mathbf{2},{ }^{13}$ though we did not have enough data to unambiguously discern between the three alternatives described in Scheme 5. We have now investigated the potential role of these mechanisms in deeper detail by a combined experimental/computational approach. We have particularly focused on the pair 1a:2, which reacts with $\mathrm{H}_{2}\left(1 \mathrm{bar}, 25^{\circ} \mathrm{C}\right)$ at a considerably slower rate and thus facilitates kinetic analysis. It is important to remark that this is the only pair in which the existence of the $\mathrm{Au} \leftarrow \mathrm{Pt}$ bond is unequivocal under all experimental conditions. In fact, we observed that hydrogen activation with 1a:2 proceeds at a slower rate when using an excess of either the $\operatorname{Au}(\mathrm{I}) \operatorname{or} \operatorname{Pt}(0)$ fragments (Figure 4), suggesting the need to access the independent $\mathrm{Au}(\mathrm{I})$ and $\mathrm{Pt}(0)$ fragments for the $\mathrm{H}-\mathrm{H}$ cleavage to take place (as in Scheme $5 \mathrm{~b}$ ). When an excess of 0.5 equiv. of the platinum precursor $\mathbf{2}$ is added, the appearance of heterobimetallic dihydride $\mathbf{3 a}$ is decelerated (Figure 3, green line), while formation of trans- $\left[\mathrm{Pt}\left(\mathrm{P}^{t} \mathrm{Bu}_{3}\right)_{2}(\mathrm{H})_{2}\right](7)$ becomes noticeable. At variance, the latter species is absent when using a 1:1 mixture of $\mathbf{1 a}$ and $\mathbf{2}$ under the same conditions. Interestingly, after $c a$. 6 hours at room temperature the excess of $\operatorname{Pt}(0)$ precursor 2 is fully converted to compound 7 , after which time the kinetic profile parallels the one that results from an equimolar ratio of $\mathrm{Au}(\mathrm{I}) / \mathrm{Pt}(0)$. Likewise, the kinetic profile derived from using an excess ( 0.5 equiv) of $\mathrm{Au}(\mathrm{I})$ evinces a detrimental effect on the $\mathrm{H}_{2}$ activation rate (orange line). These findings further support the notion of a genuine FLP mechanism which requires the initial cleavage of the Au $\leftarrow \mathrm{Pt}$ bond in $\mathbf{4 a}$. This would also explain why gold precursors $\mathbf{1 b}$ and $\mathbf{1 c}$, for which no metallic Lewis adducts with $\left[\operatorname{Pt}\left(\mathrm{P}^{t} \mathrm{Bu}_{3}\right)_{2}\right]$ are observed under identical conditions $-\mathrm{i}$. e. not involving an energetic penalty for $\mathrm{M}-\mathrm{M}$ bond cleavage- do activate $\mathrm{H}_{2}$ considerably faster. 


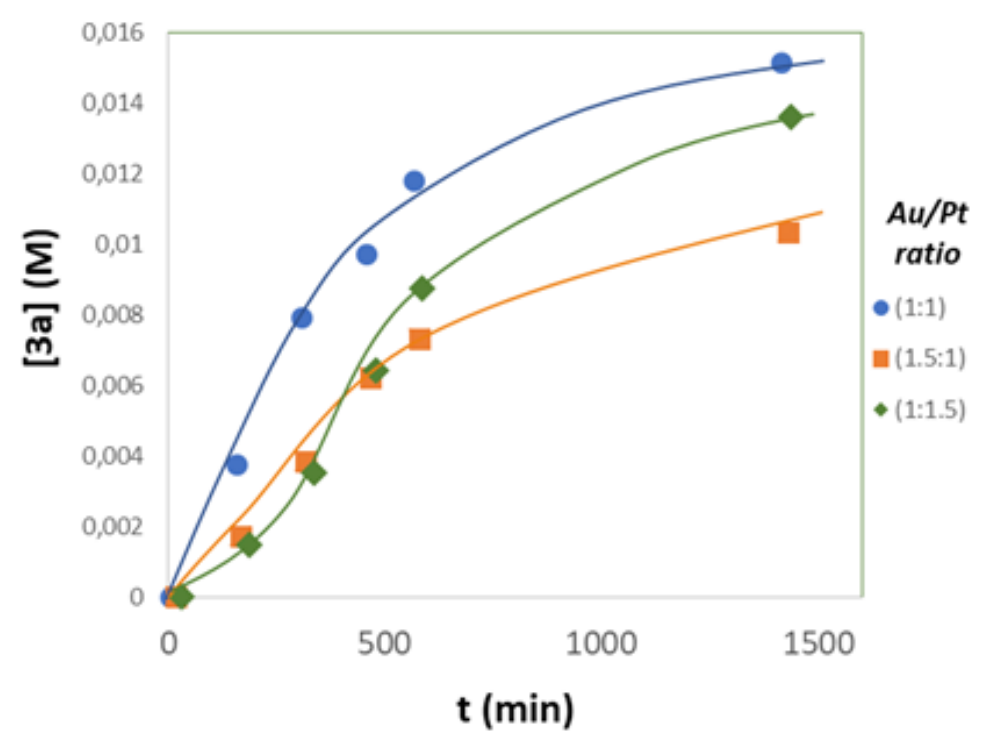

Figure 4. Reaction profile of hydrogen activation $\left(1 \mathrm{bar}, 25^{\circ} \mathrm{C}\right)$ by $\mathbf{1 a : 2}$ to yield $\mathbf{3 a}$ at variable $\mathrm{Au} / \mathrm{Pt}$ ratios monitored by ${ }^{1} \mathrm{H}$ and ${ }^{31} \mathrm{P}\left\{{ }^{1} \mathrm{H}\right\}$ NMR (lines drawn to guide the eye).

As part of our kinetic studies, we found of interest to investigate the kinetic isotopic effect derived from using deuterium instead of hydrogen. For the sake of reproducibility, we performed these experiments with crystalline samples of compound $\mathbf{4 a}$ and the reactions were performed in triplicate. The kinetic profiles were monitored by ${ }^{1} \mathrm{H}$ and ${ }^{31} \mathrm{P}\left\{{ }^{1} \mathrm{H}\right\} \quad \mathrm{NMR}$ using hexamethylbenzene, triphenylphosphine oxide or $\mathrm{PPh}_{3}$ as internal standards and after exposure to $\mathrm{H}_{2}$ or $\mathrm{D}_{2}$ ( 2 bar) at $25^{\circ} \mathrm{C}$ (see Figure $\mathrm{S} 1$ in the Supporting Information). To our surprise, we found a strongly inverse KIE of $0.46 \pm 0.04$. Puzzled by this result we performed low-temperature NMR kinetics $\left(-20{ }^{\circ} \mathrm{C}\right)$ for the activation of $\mathrm{H}_{2}$ with the $\mathbf{1 b}: 2$ couple and found an analogous strong inverse KIE that accounts for $0.50 \pm 0.02$, suggesting that both systems may share a common mechanism. Inverse KIEs are rather uncommon in the context of FLPs ${ }^{37}$ and bimetallic systems, ${ }^{38}$ though a very recent report from Mankad and Ess revealed an akin inverse KIE of 0.6 for the heterobimetallic trans-hydro(deutero)genation of alkynes using a polar ruthenium-silver complex containing a $\mathrm{Ru}-\mathrm{Ag}$ bond.$^{39}$ For that system, formation of a terminal ruthenium hydride with low-energy binding modes that contributes to an inverse equilibrium isotopic effect (EIE) is proposed to be responsible of the measured inverse KIE. In contrast to the Ru/Ag system where an inverse EIE preequilibirum is responsible for an overall inverse KIE, here we propose that our system has an inverse KIE effect in the rate-limiting transition state. ${ }^{40}$

We have considered the three scenarios for $\mathrm{H}-\mathrm{H}$ cleavage shown in Scheme 5 for the less hindered system 1a:2, for which the formation of a Lewis adduct, 4a, was confirmed experimentally. As discussed above, our calculations are consistent with this observation and indicate that 4a is $5.2 \mathrm{kcal} \cdot \mathrm{mol}^{-1}\left(\Delta G^{0}\right)$ more stable than the FLP in benzene $\left(2.5 \mathrm{kcal} \cdot \mathrm{mol}^{-1}\right.$ more stable than the separated metal fragments; Scheme 2). Interestingly, the anion $\left(\mathrm{NTf}_{2}{ }^{-}\right)$plays a key role in the reactivity of the pair as it assists the cleavage of both the Au-Pt bond of $4 \mathbf{a}\left(\Delta G^{*}=\right.$ $14.4 \mathrm{kcal} \cdot \mathrm{mol}^{-1}$; see Figure S3) and the $\mathrm{H}-\mathrm{H}$ bond by the FLP, as we shall see later. Regardless, metal-metal cooperativity was also confirmed to be instrumental in $\mathrm{H}_{2}$ activation. Firstly, while $\mathrm{H}_{2}$ oxidative addition to 2 yields the $c i s$ - $\mathrm{Pt}(\mathrm{II})$ dihydride through an accessible energy barrier $\left(\Delta G^{\ddagger}\right.$ $\left.=24.4 \mathrm{kcal} \cdot \mathrm{mol}^{-1}\right)$, the step is endergonic and cis/trans isomerization to form $\mathbf{7}$ is not feasible $\left(\Delta G^{\ddagger}=46.6 \mathrm{kcal} \cdot \mathrm{mol}^{-1}\right)$. This agrees with the absence of reactivity between $\mathrm{H}_{2}$ and 2 alone. On the other hand, whereas orthogonal reactivity, route ' $c$ ' in Scheme 5, in the presence of the Au fragment does not facilitate $\mathrm{H}_{2}$ activation by $\mathrm{Pt}$ (see SI for details), it does decrease the barrier for cis/trans isomerization by $c a .18 \mathrm{kcal} \cdot \mathrm{mol}^{-1}$, to $30 \mathrm{kcal} \cdot \mathrm{mol}^{-1}$, to yield the heterobimetallic dihydride 3a, albeit the barrier remains too high to be consistent with our experimental results. ${ }^{41}$ 
Regarding route ' $\mathrm{a}$ ', addition of $\mathrm{H}_{2}$ across the $\mathrm{Au}-\mathrm{Pt}$ bond of adduct $\mathbf{4 a}^{42}$ yields an intermediate, $\mathbf{B}$ (see Figure 5), in which the expected pair of monometallic dihydrides $\left(\mathrm{PR}_{2} \mathrm{Ar} \mathbf{A r}^{\prime}\right) \mathrm{AuH}(\mathbf{A})$, and 6 are connected by a dihydride bond. The energy barrier for this transformation $\left(\Delta G^{\ddagger}=27.8\right.$ $\mathrm{kcal} \cdot \mathrm{mol}^{-1}$ ) is only slightly lower than that found for the Au-assisted cis/trans isomerization at

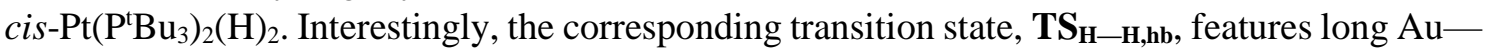
$\mathrm{Pt}$ and $\mathrm{Pt}-\mathrm{H}$ distances of 3.14 and $2.03 \AA$ respectively. AIM analysis of the electron density ${ }^{43}$ confirms bond critical points (bcps; see SI) connecting the $\mathrm{H}_{2}$ atoms, and one $\mathrm{H}$ atom to each metal at the TS, but no bcp was found connecting the metal centers. Another transition state was located when exploring route ' $b$ ', $\mathbf{T} \mathbf{S}_{\mathbf{H}-\mathbf{H}, \mathbf{F L P}}$, which corresponds to a truly FLP-type activation, resulting from the lateral attack of the donor $\mathrm{Pt}$ atom of $\mathbf{2}$ to a $\mathrm{H}_{2}$ molecule coordinated in the expected side-on fashion to the acidic $\left(\mathrm{R}_{2} \mathrm{Ar}^{\prime} \mathrm{P}\right) \mathrm{Au}^{+}$fragment. ${ }^{15 \mathrm{~b}, 44}$ Despite having different origins, this TS has a geometry comparable to $\mathbf{T S}_{\mathbf{H}-\mathbf{H}, \mathbf{h b}}$ with longer metal-metal and $\mathrm{Pt}-\mathrm{H}$ distances (4.14 and 2.78 $\mathrm{A}$ ), but similar $\mathrm{H}-\mathrm{H}$ distances and atom connectivity (AIM), in addition to comparable relative energy, $\Delta G^{\ddagger}=28.9 \mathrm{kcal} \cdot \mathrm{mol}^{-1}$.

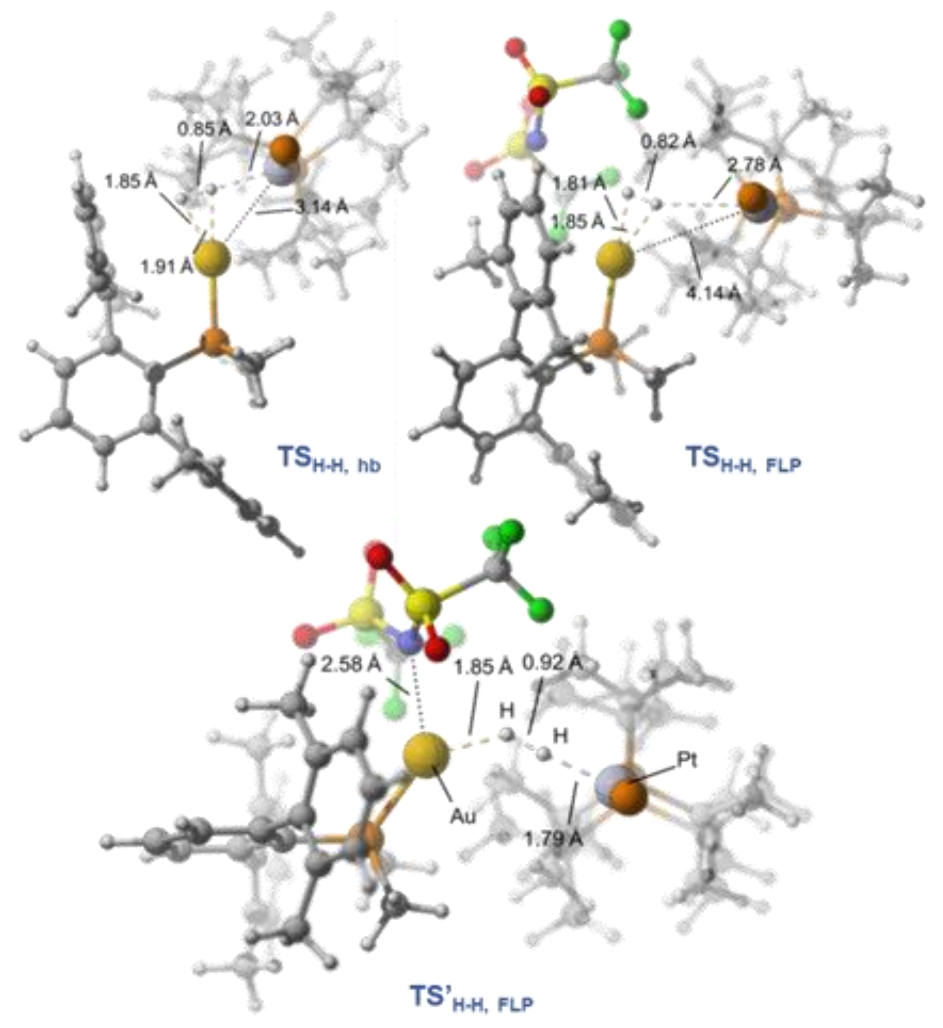

Figure 5. Transition states for heterolytic $\mathrm{H}-\mathrm{H}$ cleavage. Notice the inclusion of explicit $\mathrm{NTf}_{2}$

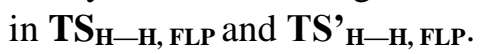

In view of the high energy barriers of the above mechanisms, and considering recent studies highlighting the key role of triflimidate and triflate counteranions in related bond activation processes ${ }^{45}$ we explored the role of $\mathrm{NTf}_{2}{ }^{-}$in $\mathrm{H}-\mathrm{H}$ cleavage. When the counter anion was allowed

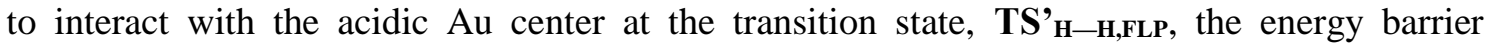
decreased by $c a .10 \mathrm{kcal} \cdot \mathrm{mol}^{-1}$ to $21.3 \mathrm{kcal} \cdot \mathrm{mol}^{-1}$ (Figure 5). This transition state features $\mathrm{Au}-\mathrm{H}$ $(1.85 \AA)$ and $\mathrm{Au}-\mathrm{Pt}(4.28 \AA)$ distances similar to $\mathbf{T} \mathbf{S}_{\mathbf{H}-\mathbf{H}, \mathbf{F L P}}$, in addition to longer $\mathrm{H}-\mathrm{H}$ distances and a short $\mathrm{Au} \cdots \mathrm{NTf}_{2}{ }^{-}$contact. Also, AIM analysis revealed an atom connectivity related to that of $\mathbf{T} \mathbf{S}_{\mathbf{H}-\mathbf{H}, \mathbf{F L P}}$, (with one additional bcp connecting the $\mathrm{Au}$ and $\mathrm{N}$ atoms; Figure $\mathrm{S} 10$, Table S3). We propose here an FLP-type $\mathrm{H}-\mathrm{H}$ cleavage which is concomitant with dissociation of the $\mathrm{Au}-\mathrm{NTf}_{2}{ }^{-}$bond of the Lewis acidic fragment. ${ }^{46}$ In addition, the intermediate

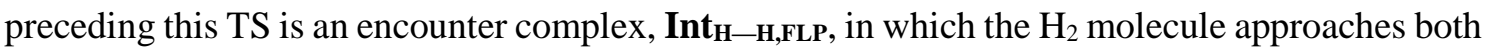


the metal centers of $\mathbf{1 a}$ and $\mathbf{2}$ in an end on fashion $\left(\mathrm{Au}-\mathrm{H}-\mathrm{H}\right.$ and $\mathrm{Pt}-\mathrm{H}-\mathrm{H}$ angles $136^{\circ}$ and $176^{\circ}$, Figure 6). Side on coordination of $\mathrm{H}_{2}$ to the acidic fragment of an FLP, with the basic fragment populating the high-lying $\sigma^{*}(\mathrm{H}-\mathrm{H})$ orbital, has been associated to high-energy "late" transition states for $\mathrm{H}_{2}$ splitting by phosphine-borane pairs, whereas low-energy "early" transition states feature "linearized" $\mathrm{L}_{\mathrm{A}}-\mathrm{H}-\mathrm{H}-\mathrm{L}_{\mathrm{B}}$ motifs. Inefficient orbital overlap in the latter is compensated by polarization of the $\mathrm{H}-\mathrm{H}$ bond in a strong electrostatic field generated by the acid and the base. ${ }^{15 a}$ In our case, $\mathbf{H} \cdots \mathbf{H}$ distances suggest that TS' ${ }_{\mathbf{H}-\mathbf{H}, \mathbf{F L P}}$ is a "geometrically

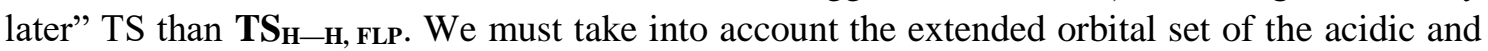
basic fragments in TMOFLPs that lead us to attribute, at least partly, the end on geometry at TS' ${ }_{\mathbf{H}-\mathbf{H}, \mathbf{F L P}}$ to the engagement of the $\mathrm{Au}$ atom in the $\mathrm{Au}-\mathrm{N}$ bond. ${ }^{44}$ This discussion relates to the two somehow antagonistic views on $\mathrm{H}_{2}$ activation by FLPs, one advocating that an orbital-based interaction, mainly populating of the $\sigma^{*}(\mathrm{H}-\mathrm{H})$ by the base, leads to destabilization of the $\mathrm{H}-\mathrm{H}$ bond in an electron transfer process, and the other attributing the main role to polarization of the $\mathrm{H}_{2}$ molecule within the electric field of the Lewis pair. ${ }^{14 b, 15 f, 47}$ It is however likely that both mechanisms contribute to a certain extent to the reaction. Our NBO analysis of the encounter complex, Int $\mathbf{H}_{\mathbf{H}-\mathbf{H}, \mathbf{F L P}}$, and $\mathbf{T S}$ ' $_{\mathbf{H}-\mathbf{H}, \mathbf{F L P}}$ discloses a synergistic transfer of electron density from one $d$ orbital on the $\mathrm{Pt}$ to the $\sigma^{*}(\mathrm{H}-\mathrm{H})$ orbital and a second donor - acceptor interaction of similar energy between the $\sigma(\mathrm{H}-\mathrm{H})$ orbital and an empty orbital (of $s$ character) on the Au center (Tables $\mathrm{S} 1$ and S2; Figures S8 and S9). This relay of electron density occurs as the $\mathrm{H}-\mathrm{H}$ bond becomes polarized at the TS, as reflected by atomic charges of -0.17 and $+0.07 \mathrm{e}-$ for the $\mathrm{Au} \cdots \mathrm{H}$ and $\mathrm{H} \cdots \mathrm{Pt}$ hydrogens respectively, compared to values close to zero in the encounter complex $(-0.04 \mathrm{e}$ - for both $\mathrm{H})$.

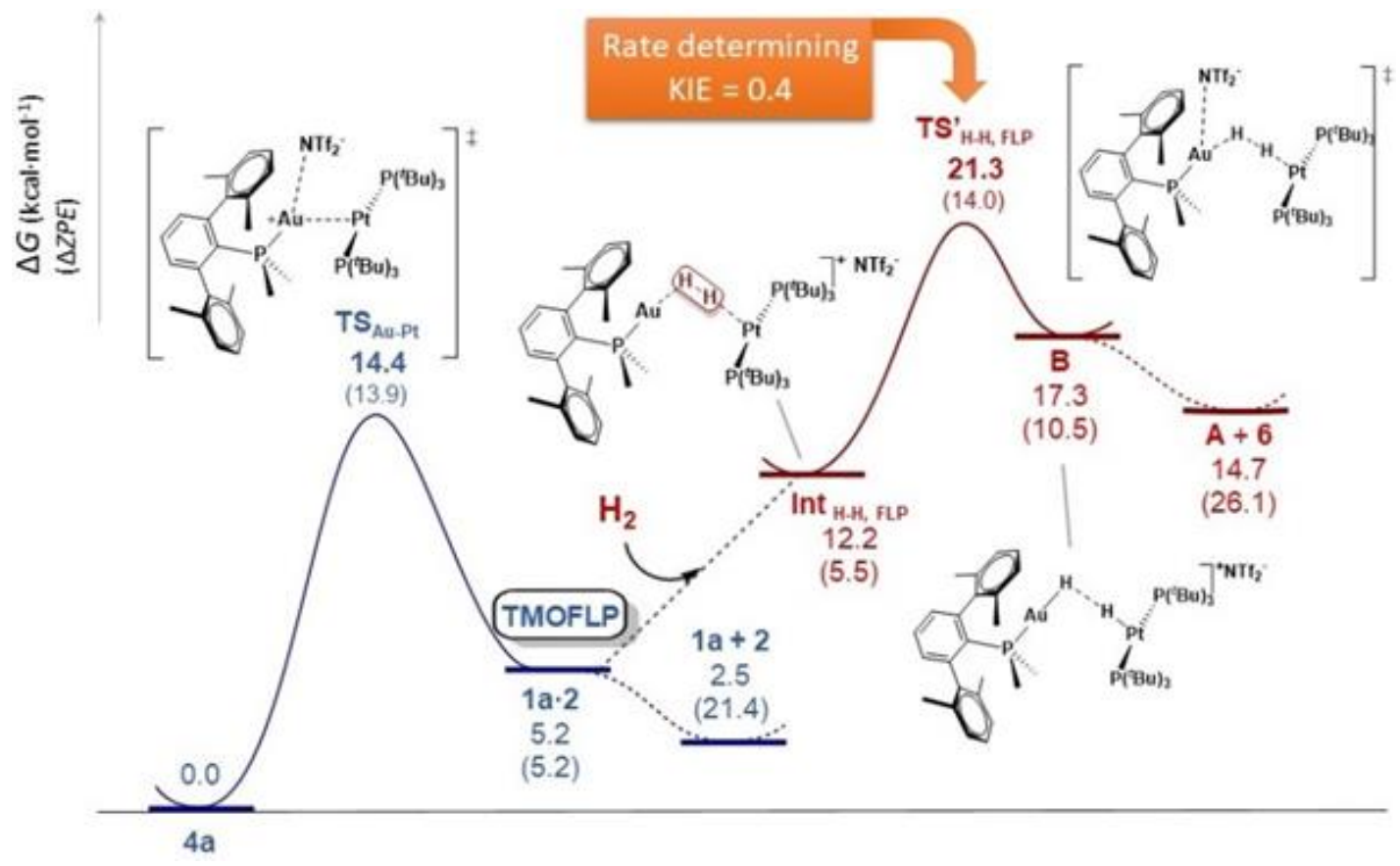

Figure 6. Calculated Free Energy profile for FLP-like, NTf2--assisted H-H cleavage by 4a. Zero-Point Energies are given in parentheses.

Once established a reasonable mechanism for $\mathrm{H}_{2}$ cleavage, we wondered whether our model could explain the inverse primary KIE measured experimentally. We thus began by analyzing the overall energy profile for $\mathrm{NTf}_{2}$ assisted $\mathrm{H}-\mathrm{H}$ cleavage. Starting from the reactants, $4 \mathbf{a}+\mathrm{H}_{2}, \mathrm{Au}-$ Pt bond cleavage to form a thermally induced FLP, 1a·2, is represented in blue trace in Figure 6. The $\mathrm{H}-\mathrm{H}$ cleavage by the FLP is represented in red. Supposing that insertion of $\mathrm{H}_{2}$ into the FLP to give the encounter complex $\mathbf{I n t}_{\mathbf{H}-\mathbf{H}, \mathbf{F L P}}$ is easy, $\mathbf{T S} \mathbf{S}_{\mathbf{H}-\mathbf{H}, \mathbf{F L P}}$ would be rate-determining. We confirmed that the latter rearrangement of metallic monohydrides towards $4 \mathbf{a}$ was easy by reacting 
the cationic Pt hydride 6 with digold hydride 5a (prepared in situ by adding $\mathrm{SiEt}_{3} \mathrm{H}$ to $1 \mathbf{a}$ at -30 ${ }^{\circ} \mathrm{C}$ ). This reaction is fast at $25{ }^{\circ} \mathrm{C}$ to yield an equimolar mixture of $\mathbf{3 a}$ and $\mathbf{1 a}$, while it offers no evidence for the formation of the Lewis adduct or $\mathrm{H}_{2}$ release.

Following the above considerations, we calculated the KIE for the reaction from the zero-point Energy differences $(\triangle \triangle Z P E)$ between the reactants, $\mathbf{4 a}+\mathrm{H}_{2} / \mathrm{D}_{2}$, and $\mathbf{T S} \mathbf{S}_{\mathbf{H}-\mathbf{H}, \mathbf{F L P}}{ }^{39,48}$ to find an inverse primary KIE $k_{\mathrm{H}} / k_{\mathrm{D}}=0.40$, in good agreement with the experiments. An (inverse) isotope effect implies the forming/breaking of $E-H(D)(E=H(D)$ or metal atom) bonds in the ratedetermining step. In our case, TS' $\mathbf{H}-\mathbf{H}$, FLP involves partial breaking of the $\mathrm{H}-\mathrm{H}(\mathrm{D}-\mathrm{D})$ bond and formation of two $\mathrm{Au}-\mathrm{H}(\mathrm{D})$ and $\mathrm{Pt}-\mathrm{H}(\mathrm{D})$ bonds. Since primary KIEs arise mainly from a balance between the changes in vibrational frequencies or bond strengths (force constant) ${ }^{49}$ between the isotopomers in the reactants and the products, our result implies stronger bonds (larger force constants) at the TS than in $\mathrm{H}-\mathrm{H} / \mathrm{D}-\mathrm{D}$. However, a normal KIE could be initially anticipated since the force constant for $\mathrm{H}-\mathrm{H}$ stretching is higher than those for $\mathrm{M}-\mathrm{H}$ stretching. Nevertheless, it must be recognized that all isotopically sensitive modes $\left(\sum v(\mathrm{H} / \mathrm{D})\right)$, including bending modes, contribute to the ZPE at the TS, i.e. it is the sum of all vibrational modes involving the forming $\mathrm{Au}-\mathrm{H}$ and $\mathrm{Pt}-\mathrm{H}$ and the breaking $\mathrm{H}-\mathrm{H}$ bonds at the TS, not only stretching modes, that determine the inverse KIE in our case (Figure 7 and Table S5). ${ }^{39,50}$

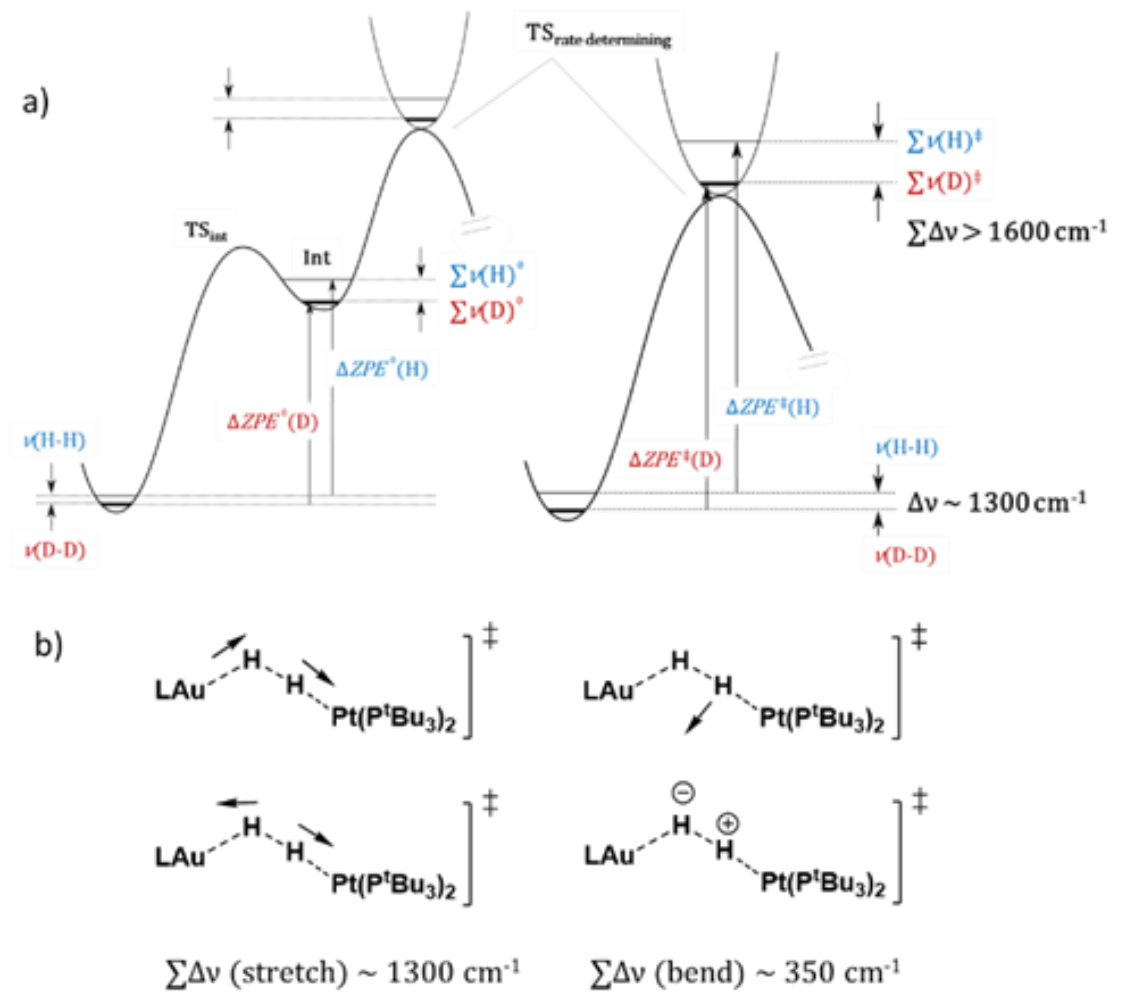

Figure 7. a) Graphical illustration of the origin of inverse KIE arising from the combination of an inverse equilibrium isotopic effect (EIE) and a normal KIE (left) versus direct one-step inverse KIE as occurs in the reported Au:Pt system (right), and b) difference in selected E-H/D vibrational frequencies $(\Delta v)$ and vector displacements at TS' ${ }_{\text {HH,FLP. }}$

The occurrence of inverse KIEs was anticipated long ago, ${ }^{51}$ and these have been shown to occur in reactions in which a preequilibrium is followed by an irreversible rate-determining step (Figure 7, left) and, although less common, there are also examples of reactions involving a single ratedetermining step (Figure 7, right). ${ }^{52}$ In the first case, the inverse KIE arises from the combination of normal KIEs and an inverse equilibrium isotope effect (EIE) resulting from the higher energy intermediate in the preequilibrium having higher force constants than the reactants [thus 
$\left.\triangle \mathrm{ZPE}^{0}(\mathrm{H})>\triangle \mathrm{ZPE}^{0}(\mathrm{D})\right] \cdot{ }^{53}$ In the second case, inverse KIEs can take place when it is the TS for the single rate-determining step which has higher force constants than the ground state $[\Delta \mathrm{ZPE}(\mathrm{H})$ $\left.\left.>\triangle \mathrm{ZPE}^{\ddagger}(\mathrm{D})\right]\right)$, being also associated with product-like transition states. ${ }^{50}$ As already stated, we do not see evidence for a pre-equilibrium and the barrier for the evolution of the monometallic hydrides to the product must be lower than the calculated reverse barrier from $\mathbf{B}$ to the encounter complex. Therefore, the observed inverse KIE should be related to $\Delta G^{t}\left(\triangle Z P E^{*}\right)$ for the FLP-type $\mathrm{H}-\mathrm{H}$ cleavage and its origin should be attributed to the collective isotopically sensitive vibrational modes $\left(\sum v(\mathrm{H} / \mathrm{D})\right)$ at the TS which is rate-determining.

\section{Conclusion}

In summary, we have demonstrated that combining a pair of sterically hindered transition metal complexes that present Lewis acidic and basic character permits the design of bimetallic frustrated Lewis pairs. Our combined experimental and computational approach strongly supports, for the first time, a genuine bimetallic FLP mechanism for the heterolytic cleavage of $\mathrm{H} 2$, where both electron transfer (ET) and electric field (EF) mechanistic interpretations may be concurrently operating. These studies additionally revealed an uncommon strong inverse kinetic isotopic effect (KIE) whose origin opposes the traditional view based on an inverse equilibrium isotopic effect (EIE) prior to an irreversible rate-determining step, while rather suggesting a single ratedetermining step featuring a strong inverse KIE. Also contrasting with previous studies on heterobimetallic complexes, we have now proved the importance of forcing steric frustration to drastically enhance small molecule activation capacity in bimetallic systems. This knowledge will be of importance for the design of novel cooperative bimetallic catalysts, a continuously growing area of research that could benefit from introducing the concept of (induced) frustration.

\section{Experimental Section}

General considerations. All preparations and manipulations were carried out using standard Schlenk and glove-box techniques, under an atmosphere of argon and of high purity nitrogen, respectively. All solvents were dried, stored over $4 \AA$ molecular sieves, and degassed prior to use. Toluene $\left(\mathrm{C}_{7} \mathrm{H}_{8}\right)$ and n-pentane $\left(\mathrm{C}_{5} \mathrm{H}_{12}\right)$ were distilled under nitrogen over sodium. Tetrahydrofuran (THF) and diethyl ether were distilled under nitrogen over sodium/benzophenone. [ $\mathrm{D}_{6}$ ] Benzene was dried over molecular sieves $(4 \AA)$ and $\mathrm{CD}_{2} \mathrm{Cl}_{2}$ over $\mathrm{CaH}_{2}$ and distilled under argon. [AuCl(THT)] (THT =tetrahydrothiophene) ${ }^{55}$ phosphine ligands $\mathrm{PMe}_{2} \mathrm{Ar}^{\mathrm{Dipp} 2}{ }^{54} \mathrm{PMe}_{2} \mathrm{Ar}^{\mathrm{Xy12}},{ }^{42} \mathrm{PCyp}_{2} \mathrm{Ar}^{\mathrm{Xy12}}{ }^{42}$ and compounds $\mathbf{1 a}^{26}$ and $\mathbf{2}^{56}$ were prepared as described previously. Other chemicals were commercially available and used as received. Solution NMR spectra were recorded on Bruker AMX-300, DRX-400 and DRX-500 spectrometers. Spectra were referenced to external $\mathrm{SiMe}_{4}(\delta: 0 \mathrm{ppm})$ using the residual proton solvent peaks as internal standards $\left({ }^{1} \mathrm{H}\right.$ NMR experiments), or the characteristic resonances of the solvent nuclei ( ${ }^{13} \mathrm{C}$ NMR experiments), while ${ }^{31} \mathrm{P}$ was referenced to $\mathrm{H}_{3} \mathrm{PO}_{4}$. Spectral assignments were made by routine one- and two-dimensional NMR experiments where appropriate (Figure 10). Infrared spectra were recorded on a Bruker Vector 22 spectrometer and sampling preparation was made in Nujol. For elemental analyses a LECO TruSpec CHN elementary analyzer, was utilized. CCDC 1965523-1965526 contain the supplementary crystallographic data for this paper. These data can be obtained free of charge from The Cambridge Crystallographic Data Centre. 


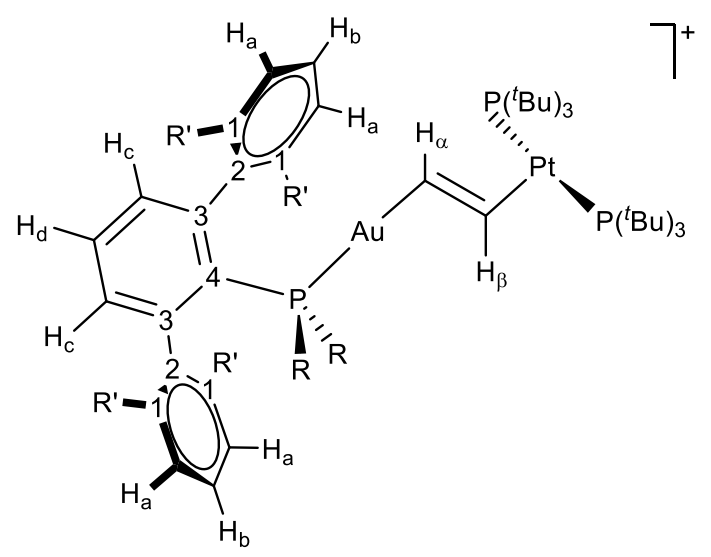

Figure 10. Labeling scheme used for ${ }^{1} \mathrm{H}$ and ${ }^{13} \mathrm{C}\left\{{ }^{1} \mathrm{H}\right\}$ NMR assignments.

[(PMe $\left.\left.\mathbf{A r}^{\mathbf{X y l} \mathbf{2}}\right) \mathbf{A u}(\boldsymbol{\mu}-\mathbf{H}) \mathbf{P t}(\mathbf{H})\left(\mathbf{P}^{t} \mathbf{B u}_{3}\right)_{2}\right] \mathbf{N T f}_{2}$ (3a). A mixture of compounds $\mathbf{1 a}(100 \mathrm{mg}, 0.121$ $\mathrm{mmol})$ and $2(73 \mathrm{mg}, 0.121 \mathrm{mmol})$ was placed in a Schlenk inside a dry box, dissolved in toluene $(5 \mathrm{~mL})$ and stirred at room temperature for 48 hours under $\mathrm{H}_{2}$ atmosphere $(1 \mathrm{bar})$. The solution was layered with pentane $(10 \mathrm{~mL})$ and stored at $-30{ }^{\circ} \mathrm{C}$ overnight to yield compound $\mathbf{3 a}$ as yellow crystals $(86 \mathrm{mg}, 50 \%)$. Anal. Calcd. for $\mathrm{C}_{50} \mathrm{H}_{83} \mathrm{AuF}_{6} \mathrm{NO}_{4} \mathrm{P}_{3} \mathrm{PtS}_{2}: \mathrm{C}, 42.1 ; \mathrm{H}, 5.9 ; \mathrm{N}, 1.0 ; \mathrm{S}, 4.5$. Found: C, 42.5; H, 5.8; N, 0.9; S, 4.1. ${ }^{1} \mathrm{H}$ NMR $\left(400 \mathrm{MHz}, \mathrm{C}_{6} \mathrm{D}_{6}, 25{ }^{\circ} \mathrm{C}\right) \delta: 7.15\left(\mathrm{t}, 2 \mathrm{H},{ }^{3} \mathrm{~J}_{\mathrm{HH}}=\right.$ $\left.7.6 \mathrm{~Hz}, \mathrm{H}_{\mathrm{b}}\right), 7.07\left(\mathrm{~d}, 4 \mathrm{H},{ }^{3} J_{\mathrm{HH}}=7.6 \mathrm{~Hz}, \mathrm{H}_{\mathrm{a}}\right), 7.05\left(\mathrm{td}, 1 \mathrm{H},{ }^{3} J_{\mathrm{HH}}=7.6 \mathrm{~Hz},{ }^{5} J_{\mathrm{HP}}=1.8 \mathrm{~Hz}, \mathrm{H}_{\mathrm{d}}\right), 6.60$ $\left(\mathrm{dd}, 2 \mathrm{H},{ }^{3} J_{\mathrm{HH}}=7.6 \mathrm{~Hz},{ }^{4} J_{\mathrm{HP}}=3.4 \mathrm{~Hz}, \mathrm{H}_{\mathrm{c}}\right), 2.04\left(\mathrm{~s}, 12 \mathrm{H}, \mathrm{Me}_{\mathrm{Xyl}}\right), 1.31\left(\mathrm{vt}, 54 \mathrm{H},{ }^{3} J_{\mathrm{HP}}=6.4 \mathrm{~Hz}\right.$, $\left.{ }^{\mathrm{t}} \mathrm{Bu}\right), 1.28\left(\mathrm{~d}, 6 \mathrm{H},{ }^{2} J_{\mathrm{HP}}=9.5 \mathrm{~Hz}, \mathrm{PMe} 2\right),-1.75\left(\mathrm{~m}, 1 \mathrm{H},{ }^{2} J_{\mathrm{HP}}=110 \mathrm{~Hz},{ }^{1} J_{\mathrm{HPt}}=516 \mathrm{~Hz}, \mathrm{Au}(\mu-\mathrm{H}) \mathrm{Pt}\right)$, $-10.39\left(\mathrm{~m}, 1 \mathrm{H},{ }^{1} J_{\mathrm{HPt}}=1030 \mathrm{~Hz}, \mathrm{Pt}-\mathrm{H}\right) .{ }^{13} \mathrm{C}\left\{{ }^{1} \mathrm{H}\right\} \mathrm{NMR}\left(100 \mathrm{MHz}, \mathrm{C}_{6} \mathrm{D}_{6}, 25{ }^{\circ} \mathrm{C}\right) \delta: 146.6\left(\mathrm{~d},{ }^{2} J_{\mathrm{CP}}\right.$ $\left.=10 \mathrm{~Hz}, \mathrm{C}_{3}\right), 140.8\left(\mathrm{~d},{ }^{3} J_{\mathrm{CP}}=4 \mathrm{~Hz}, \mathrm{C}_{2}\right), 136.5\left(\mathrm{C}_{1}\right), 132.1\left(\mathrm{CH}_{\mathrm{d}}\right), 131.3\left(\mathrm{~d},{ }^{3} J_{\mathrm{CP}}=7 \mathrm{~Hz}, \mathrm{CH}_{\mathrm{c}}\right)$, $129.1\left(\mathrm{CH}_{\mathrm{b}}\right), 128.5\left(\mathrm{CH}_{\mathrm{a}}\right), 121.4\left(\mathrm{q},{ }^{1} J_{\mathrm{CF}}=323 \mathrm{~Hz}, \mathrm{CF}_{3}\right), 39.4\left(\mathrm{vt},{ }^{1} J_{\mathrm{CP}}=8 \mathrm{~Hz},{ }^{2} J_{\mathrm{CPt}}=30 \mathrm{~Hz}, \mathrm{Pt}-\right.$ $\left.C\left(\mathrm{CH}_{3}\right)_{3}\right), 32.9\left(\mathrm{Pt}-\mathrm{C}\left(\mathrm{CH}_{3}\right)_{3}\right), 22.1\left(\mathrm{Me}_{\mathrm{Xyl}}\right), 17.4\left(\mathrm{~d},{ }^{1} J_{\mathrm{CP}}=7 \mathrm{~Hz}, \mathrm{PMe}_{2}\right)$. The quaternary carbon $\mathrm{C}_{4}$ could not be located neither in the ${ }^{13} \mathrm{C}\left\{{ }^{1} \mathrm{H}\right\}$ NMR spectrum or by two-dimensional ${ }^{1} \mathrm{H}-{ }^{13} \mathrm{C}$ correlations. ${ }^{31} \mathrm{P}\left\{{ }^{1} \mathrm{H}\right\} \mathrm{NMR}\left(160 \mathrm{MHz}, \mathrm{C}_{6} \mathrm{D}_{6}, 25{ }^{\circ} \mathrm{C}\right) \delta: 91.5\left({ }^{1} J_{\mathrm{PPt}}=2713 \mathrm{~Hz}, \mathrm{P}\left({ }^{\mathrm{t}} \mathrm{Bu}\right)_{3}\right), 5.7\left({ }^{2} J_{\mathrm{PPt}}\right.$ $=208 \mathrm{~Hz}, \mathrm{Au}-\mathrm{P})$. IR (Nujol): $v(\mathrm{Pt} / \mathrm{Au}-\mathrm{H}) 2290,2165 \mathrm{~cm}^{-1}$.

[(PMe $\left.\left.\mathbf{P r}^{\mathbf{X y l} \mathbf{2}}\right) \mathbf{A u}-\mathbf{P t}\left(\mathbf{P}^{t} \mathbf{B u}_{3}\right)_{2}\right] \mathbf{N T f}_{\mathbf{2}}$ (4a). To a solid mixture of $\mathbf{1 a}(100 \mathrm{mg}, 0.121 \mathrm{mmol})$ and $\mathbf{2}$ (73 mg, $0.121 \mathrm{mmol}$ ) was added $5 \mathrm{~mL}$ of toluene and the solution stirred at room temperature for 10 minutes. Addition of pentane $(10 \mathrm{~mL})$ caused precipitation of an orange solid $(160 \mathrm{mg}, 93 \%)$ that was washed with pentane. Single crystals of $\mathbf{4 a}$ suitable for X-ray diffraction studies were grown by diffusion of pentane into a toluene solution of $6 \mathrm{~b}(1: 2 \mathrm{by}$ vol. $)$ at $-20^{\circ} \mathrm{C}$. Anal. Calcd. for $\mathrm{C}_{50} \mathrm{H}_{81} \mathrm{AuF}_{6} \mathrm{NO}_{4} \mathrm{P}_{3} \mathrm{PtS}_{2}: \mathrm{C}, 42.2 ; \mathrm{H}, 5.7 ; \mathrm{N}, 1.0 ; \mathrm{S}, 4.5$. Found: $\mathrm{C}, 42.4 ; \mathrm{H}, 5.6 ; \mathrm{N}, 1.0 ; \mathrm{S}, 4.4$. ${ }^{1} \mathrm{H} \mathrm{NMR}\left(400 \mathrm{MHz}, \mathrm{CD}_{2} \mathrm{Cl}_{2}, 25{ }^{\circ} \mathrm{C}\right) \delta: 7.62\left(\mathrm{td}, 1 \mathrm{H},{ }^{3} J_{\mathrm{HH}}=7.6 \mathrm{~Hz},{ }^{5} J_{\mathrm{HP}}=1.8 \mathrm{~Hz}, \mathrm{H}_{\mathrm{d}}\right), 7.26(\mathrm{t}, 2$ $\left.\mathrm{H},{ }^{3} J_{\mathrm{HH}}=7.6 \mathrm{~Hz}, \mathrm{H}_{\mathrm{b}}\right), 7.13\left(\mathrm{~d}, 4 \mathrm{H},{ }^{3} J_{\mathrm{HH}}=7.6 \mathrm{~Hz}, \mathrm{H}_{\mathrm{a}}\right), 7.03\left(\mathrm{dd}, 2 \mathrm{H},{ }^{3} J_{\mathrm{HH}}=7.6 \mathrm{~Hz},{ }^{4} J_{\mathrm{HP}}=3.3\right.$ $\left.\mathrm{Hz}, \mathrm{H}_{\mathrm{c}}\right), 2.11\left(\mathrm{~s}, 12 \mathrm{H}, \mathrm{Me}_{\mathrm{Xyl}}\right), 1.52\left(\mathrm{vt}, 54 \mathrm{H},{ }^{3} J_{\mathrm{HP}}=6.5 \mathrm{~Hz},{ }^{\mathrm{t}} \mathrm{Bu}\right), 1.08\left(\mathrm{~d}, 6 \mathrm{H},{ }^{2} J_{\mathrm{HP}}=10 \mathrm{~Hz}\right.$, $\left.\mathrm{PMe}_{2}\right) .{ }^{13} \mathrm{C}\left\{{ }^{1} \mathrm{H}\right\}$ NMR $\left(100 \mathrm{MHz}, \mathrm{CD}_{2} \mathrm{Cl}_{2}, 25{ }^{\circ} \mathrm{C}\right) \delta: 145.8\left(\mathrm{~d},{ }^{2} J_{\mathrm{CP}}=10 \mathrm{~Hz}, \mathrm{C}_{3}\right), 141.2\left(\mathrm{~d},{ }^{3} J_{\mathrm{CP}}=\right.$ $\left.4 \mathrm{~Hz}, \mathrm{C}_{2}\right), 136.7\left(\mathrm{C}_{1}\right), 132.3\left(\mathrm{CH}_{\mathrm{d}}\right), 132.2\left(\mathrm{~d},{ }^{3} J_{\mathrm{CP}}=7 \mathrm{~Hz}, \mathrm{CH}_{\mathrm{c}}\right), 129.0\left(\mathrm{CH}_{\mathrm{b}}\right), 128.4\left(\mathrm{CH}_{\mathrm{a}}\right), 126.2$ $\left(\mathrm{d},{ }^{1} J_{\mathrm{CP}}=52 \mathrm{~Hz}, \mathrm{C}_{4}\right), 122.2\left(\mathrm{q},{ }^{1} J_{\mathrm{CF}}=323 \mathrm{~Hz}, \mathrm{CF}_{3}\right), 39.4\left(\mathrm{vt},{ }^{1} J_{\mathrm{CP}}=8 \mathrm{~Hz},{ }^{2} J_{\mathrm{CPt}}=20 \mathrm{~Hz}, \mathrm{Pt}-\right.$ $\mathrm{P}\left(C\left(\mathrm{CH}_{3}\right)_{3}\right), 33.8\left(\mathrm{Pt}-\mathrm{P}\left(\mathrm{C}\left(\mathrm{CH}_{3}\right)_{3}\right), 22.3\left(\mathrm{Me}_{\mathrm{Xyl}}\right), 18.7\left(\mathrm{~d},{ }^{1} J_{\mathrm{CP}}=36 \mathrm{~Hz}, \mathrm{PMe}_{2}\right) .{ }^{31} \mathrm{P}\left\{{ }^{1} \mathrm{H}\right\} \mathrm{NMR}(160\right.$ $\left.\mathrm{MHz}, \mathrm{CD}_{2} \mathrm{Cl}_{2}, 25{ }^{\circ} \mathrm{C}\right) \delta: 96.4\left(\mathrm{~d},{ }^{3} J_{\mathrm{PP}}=3 \mathrm{~Hz},{ }^{1} J_{\mathrm{PPt}}=3140 \mathrm{~Hz}, \mathrm{P}\left({ }^{\mathrm{t} B u}\right)_{3}\right),-32.5\left(\mathrm{t},{ }^{3} J_{\mathrm{PP}}=3 \mathrm{~Hz},{ }^{2} J_{\mathrm{PPt}}\right.$ $=1933 \mathrm{~Hz}, \mathrm{Au}-\mathrm{P})$.

$\left[\left\{\left(\mathbf{P C y p}_{2} \mathbf{A r}^{\mathbf{X y l 2}}\right) \mathbf{A u}\right\}_{2}(\boldsymbol{\mu}-\mathbf{H})\right] \mathbf{N T f}_{\mathbf{2}} \mathbf{( 5 \mathbf { c } )}$. A mixture of compounds $\mathbf{1 c}(100 \mathrm{mg}, 0.107 \mathrm{mmol})$ and $\mathbf{2}$ (64 mg, $0.107 \mathrm{mmol}$ ) was placed in a Schlenk inside a dry box, dissolved in toluene $(5 \mathrm{~mL})$ and stirred at room temperature for 48 hours under $\mathrm{H}_{2}$ atmosphere ( 1 bar). The solution was layered with pentane and stored at $-20{ }^{\circ} \mathrm{C}$ overnight to yield compound $\mathbf{5 c}$ as yellow crystals ( $94 \mathrm{mg}, 56$ $\%)$. Compound $7 \mathrm{c}$ can be alternatively synthesized by adding $\operatorname{SiEt}_{3} \mathrm{H}(51 \mu \mathrm{L}, 0.321 \mathrm{mmol})$ to a 
toluene solution $(10 \mathrm{~mL})$ of $1 \mathrm{c}(100 \mathrm{mg}, 0.107 \mathrm{mmol})$ after stirring at room temperature for 30 minutes. Subsequent addition of pentane $(10 \mathrm{~mL})$ caused precipitation of a white solid that was washed with pentane and dried to provide compound $7 \mathrm{c}(147 \mathrm{mg}, 87 \%) .{ }^{1} \mathrm{H}$ NMR $(400 \mathrm{MHz}$, $\left.\mathrm{C}_{6} \mathrm{D}_{6}, 25{ }^{\circ} \mathrm{C}\right) \delta: 7.22\left(\mathrm{~m}, 12 \mathrm{H},{ }^{3} J_{\mathrm{HH}}=7.6 \mathrm{~Hz}, \mathrm{H}_{\mathrm{a}}, \mathrm{H}_{\mathrm{b}}\right), 7.12\left(\mathrm{td}, 2 \mathrm{H},{ }^{3} J_{\mathrm{HH}}=7.6 \mathrm{~Hz},{ }^{5} J_{\mathrm{HP}}=1.6 \mathrm{~Hz}\right.$, $\left.\mathrm{H}_{\mathrm{d}}\right), 6.66\left(\mathrm{dd}, 4 \mathrm{H},{ }^{3} J_{\mathrm{HH}}=7.6 \mathrm{~Hz},{ }^{4} J_{\mathrm{HP}}=3.0 \mathrm{~Hz}, \mathrm{H}_{\mathrm{c}}\right), 4.78\left(\mathrm{t}, 1 \mathrm{H},{ }^{2} J_{\mathrm{HP}}=90.9 \mathrm{~Hz}, \mathrm{Au}-\mathrm{H}-\mathrm{Au}\right), 2.36-$ 2.24 (m, $4 \mathrm{H}, \mathrm{PCH}), 2.01$ (s, $\left.24 \mathrm{H}, \mathrm{Me}_{\mathrm{Xyl}}\right), 1.82-1.34\left(\mathrm{~m}, 32 \mathrm{H}, \mathrm{CH}_{2}\right) .{ }^{13} \mathrm{C}\left\{{ }^{1} \mathrm{H}\right\} \mathrm{NMR}(100 \mathrm{MHz}$, $\left.\mathrm{C}_{6} \mathrm{D}_{6}, 25^{\circ} \mathrm{C}\right) \delta: 148.1\left(\mathrm{~d},{ }^{2} J_{\mathrm{CP}}=9 \mathrm{~Hz}, \mathrm{C}_{3}\right), 141.1\left(\mathrm{~d},{ }^{3} J_{\mathrm{CP}}=5 \mathrm{~Hz}, \mathrm{C}_{2}\right), 136.8\left(\mathrm{C}_{1}\right), 136.5\left(\mathrm{~d},{ }^{3} J_{\mathrm{CP}}=\right.$ $\left.7 \mathrm{~Hz}, \mathrm{CH}_{\mathrm{c}}\right), 132.4\left(\mathrm{~d},{ }^{4} J_{\mathrm{CP}}=8 \mathrm{~Hz}, \mathrm{CH}_{\mathrm{d}}\right), 131.9\left(\mathrm{~d},{ }^{1} J_{\mathrm{CP}}=40 \mathrm{~Hz}, \mathrm{C}_{4}\right), 129.1\left(\mathrm{CH}_{\mathrm{b}}\right), 128.7\left(\mathrm{CH}_{\mathrm{a}}\right)$, $120.4\left(\mathrm{q},{ }^{1} J_{\mathrm{CF}}=323 \mathrm{~Hz}, \mathrm{CF}_{3}\right), 38.4\left(\mathrm{~d},{ }^{1} J_{\mathrm{CP}}=33 \mathrm{~Hz}, \mathrm{PCH}\right), 35.6\left(\mathrm{~d},{ }^{2} J_{\mathrm{CP}}=10 \mathrm{~Hz}, \mathrm{CH}_{2}\right), 32.8(\mathrm{~d}$, $\left.{ }^{2} J_{\mathrm{CP}}=10 \mathrm{~Hz}, \mathrm{CH}_{2}\right), 25.4\left(\mathrm{~d},{ }^{2} J_{\mathrm{CP}}=10 \mathrm{~Hz}, \mathrm{CH}_{2}\right), 25.2\left(\mathrm{~d},{ }^{2} J_{\mathrm{CP}}=10 \mathrm{~Hz}, \mathrm{CH}_{2}\right), 21.5\left(\mathrm{Me}_{\mathrm{Xyl}}\right) .{ }^{31} \mathrm{P}\left\{{ }^{1} \mathrm{H}\right\}$ NMR (160 MHz, $\left.\mathrm{C}_{6} \mathrm{D}_{6}, 25^{\circ} \mathrm{C}\right) \delta: 58.0$. IR (Nujol): v(Au-H) $1922 \mathrm{~cm}^{-1}$.

Computational details. Geometry optimization of minima and transition states was carried out with the Gaussian software package. ${ }^{57}$ Optimizations were carried out without symmetry restrictions using the $\omega \mathrm{B} 97 \mathrm{xD}$ functional ${ }^{58}$ that includes empirical dispersion corrections. ${ }^{59}$ The 6-31 $\mathrm{g}(\mathrm{d}, \mathrm{p})$ basis set ${ }^{60}$ was used for non-metal atoms, Au and Pt atoms were described with the SDD basis and associated electron core potential (ECP) ${ }^{61}$ Bulk solvent effects (benzene and dichloromethane) were included during optimization with the SMD continuum model. ${ }^{62}$ Vibrational analysis was carried out on the stationary points to characterize them as minima or transition states as well as to calculate the zero-point corrections, and thermal corrections to enthalpy and free energy. Free energies were corrected $\left(\Delta G_{\mathrm{qh}}\right)$ to account for errors associated with the harmonic oscillator approximation. Thus, according to Truhlars's quasi harmonic approximation, all vibrational frequencies below $100 \mathrm{~cm}^{-1}$ were set to this value so that the entropy contribution is not overestimated. ${ }^{63}$ These anharmonic corrections were calculated with the Goodvibes code. ${ }^{64} \mathrm{NBO}$ analysis was performed with the NBO6.0 suite. ${ }^{65}$ Analysis of the electron density was performed within the Atoms In Molecules (AIM) theory of R. F. W. Bader ${ }^{66}$ using the Multiwfn program. ${ }^{67}$ The CYLview visualization software has been used to create some of the figures. ${ }^{68}$

\section{Acknowledgements}

This work has been supported by the European Research Council (ERC Starting Grant, CoopCat, Project 756575) and by by the Spanish Ministry of Economy and Competitiveness (Project CTQ2016-75193-P [AEI/ FEDER, UE]). J. J. M. and M. P.-J. thank the University of Sevilla and the Ministry of Science, Innovation and Universities, respectively, for $\mathrm{PhD}$ fellowships. The use of computational facilities at the Supercomputing Centre of Galicia (CESGA) and the Centro de Servicios de Informática y Redes de Comunicaciones (CSIRC), Universidad de Granada are acknowledged. We are grateful to M. Roselló for valuable discussions.

Keywords: Metal Frustrated Lewis Pair • Cooperative Chemistry $\bullet$ Hydrogen Splitting $\bullet$ Inverse Kinetic Isotopic Effect $•$ Bimetallic Complexes

\section{References}

[1] a) D. W. Stephan and G. Erker, Angew. Chem. Int. Ed. 2015, 54, 6400 - 6441; b) D. W. Stephan and G. Erker, Top. Curr. Chem. 2013, 334, 1; c) D. W. Stephan and G. Erker, Top. Curr. Chem. 2013, 332, 1; d) D. W. Stephan and G. Erker, Angew. Chem. Int. Ed. 2010, 49, 46 - 76; e) D. W. Stephan, J. Am. Chem. Soc. 2015, 137, 10018 - 10032; f) D. W. Stephan, Science, 2016, 354, aaf7229; g) A. R. Jupp and D. W. Stephan, Trends in Chemistry 2019, 1, 35 -48.

[2] D. W. Stephan, Dalton Trans. 2009, 3129 - 3136; b) D. W. Stephan, Org. Biomol. Chem. 2012, 10, 5740 - 5746; c) D. W. Stephan, Acc. Chem. Res. 2015, 48, 306 - 316. 
[3] a) A. Y. Houghton, J. Hurmalainen, A. Mansikkamäki, W. E. Piers and H. M. Tuononen, Nat. Chem. 2014, 6, 983 - 988; b) X. Feng and H. Du, Tetrahedron Letters 2014, 55, 6959 - 6964.

[4] a) M. A. Courtemanche, M. A. Légaré, L. Maron and F. G. Fontaine, J. Am. Chem. Soc. 2013, 135, 9326 - 9329; b) T. Wang and D. W. Stephan, Chem. Eur. J. 2014, 20, 3036 - 3039; c) P. Vasko, I. A. Zulkifly, M. A. Fuentes, Z. Mo, J. Hicks, P. C. J. Kamer and S. Aldridge, Chem. Eur. J. 2018, 24, 10531 - 10540; d) A. Jayaraman, L. C. M. Castro and F-G. Fontaine, Org. Process Res. Dev. 2018, 22, 1489 - 1499.

[5] T. Mahdi and D. W. Stephan, Angew. Chem. Int. Ed. 2013, 52, 12418 - 12421.

[6] a) Z. Mo, A. Rit, J. Campos, E. L. Kolychev and S. Aldridge, J. Am. Chem. Soc. 2016, 138, 3306 - 3309; b) G. Ma, G. Song and Z. H. Li, Chem. Eur. J. 2018, 24, 13238 - 13245.

[7] See for example: a) M.-A. Légaré, M.-A. Courtemanche, E. Rochette and F.-G. Fontaine, Science 2015, 349, 513 - 516; b) M. Bakos, A. Gyömöre, A. Domján and T. Soós, Angew. Chem. 2017, 129, 5301 - 5305; c) Y. Han, S. Zhang, J. He and Y. Zhang, ACS Catal. 2018, 8, 8765 8773; d) J. L. Lavergne, A. Jayaraman, L. C. M. Castro, E. Rochette and F-G. Fontaine, J. Am. Chem. Soc. 2017, 139, $14714-14723$.

[8] S. R. Flynn and Wass, D. F. ACS Catal. 2013, 3, $2574-2581$.

[9] a) A. M. Chapman, M. F. Haddow and D. F. Wass, Eur. J. Inorg. Chem. 2012, 9, 1546 - 1554; b) O. J. Metters, S. J. K. Forrest, H. A. Sparkes, I. Manners and D. F. Wass, J. Am. Chem. Soc. 2016, 138, $1994-2003$; c) A. M. Chapman, M. F. Haddow and D. F. Wass, J. Am. Chem. Soc. 2011, 133, 18463 - 18478; d) S. R. Flynn, O. J. Metters, I. Manners and D. F. Wass, Organometallics 2016, 35, 847 - 850; e) O. J. Metters, S. R. Flynn, C. K. Dowds, H. A. Sparkes, I. Manners and D. F. Wass, ACS Catal. 2016, 6, $6601-6611$; f) H. B. Hamilton, A. M. King, H. A. Sparkes, N. E. Pridmore and D. F. Wass, Inorg. Chem. 2019, 58, $6399-6409$.

[10] a) G. Erker, Dalt. Trans. 2011, 40, 7475 - 7483; b) X. Xu, G. Kehr, C. G. Daniliuc and G. Erker, Angew. Chem. Int. Ed. 2013, 52, 13629 - 13632; c) X. Xu, G. Kehr, C. G. Daniliuc and G. Erker, J. Am. Chem. Soc. 2013, 135, 6465 - 6476; d) A. T. Normand, P. Richard, C. Balan, C. G. Daniliuc, G. Kehr, G. Erker and P. Le Gendre, Organometallics 2015, 34, 2000 - 2011; e) A. T. Normand, C. G. Daniliuc, B. Wibbeling, G. Kehr, P. Le Gendre and G. Erker, J. Am. Chem. Soc. 2015, 137, 10796 - 10808; f) Y. Hasegawa, G. Kehr, S. Ehrlich, S. Grimme, C. G. Daniliuc and G. Erker, Chem. Sci. 2014, 5, 797 - 803; g) X. Xu, G. Kehr, C. G. Daniliuc and G. Erker, Organometallics 2015, 34, 2655 - 2661; h) Z. Jian, C. G. Daniliuc, G. Kehra and G. Erker, Organometallics 2017, 36, 424-434.

[11] See for example: a) Y. Jiang, O. Blacque, T. Fox and H. Berke, J. Am. Chem. Soc. 2013, 135, 7751-7760; b) A. Simonneau, R. Turrel, L. Vendier and M. Etienne, Angew. Chem. Int. Ed. 2017, 56, $12268-12272$; c) M. M. Rahman, M. D. Smith, J. A. Amaya, T. M. Makris and D. V. Peryshkov, Inorg. Chem. 2017, 56, $11798-11803$; d) P. Cui, C. C. Comanescu and V. M. Iluc, Chem. Commun. 2015, 51, 6206 - 6209; e) K. Chang and X. Xu, Dalton Trans. 2017, 46, 4514 4517; f) Z. Wang, A. Ying, Z. Fan, C. Hervieu and L. Zhang, ACS Catal. 2017, 7, $3676-3680$; g) B. R. Barnett, M. L. Neville, C. E. Moore, A. L. Rheingold and J. S. Figueroa, Angew. Chem. Int. Ed. 2017, 129, 7301 - 7305; h) S. Zhang, A. M.; Appel and R. M. Bullock, J. Am. Chem. Soc. 2017 139, 7376 - 7387; i) S. Arndt, M. Rudolph and A. S. K. Hashmi, Gold Bulletin, 2017, 50, $267-282 ;$ j) N. Zwettler, S. P. Walg, F. Belaj and N. C. Mösch-Zanetti, Chemistry, 2018, 24, $7149-7160 ; \mathrm{k})$ K. Chang, X. Wang, Z. Fan and X. Xu, Inorg. Chem. 2018, 57, $8568-8580$.

[12] A. M. Chapman, S. R. Flynn and D. F. Wass, Inorg. Chem. 2016, 55, 1017 - 1021.

[13] J. Campos, J. Am. Chem. Soc., 2017, 139, 2944 - 2947. 
[14] a) T. A. Rokob and I. Pápai, Top. Curr. Chem. 2013, 332, 157-211; b) J. Paradies, Eur. J. Org. Chem. 2019, 283-294; c) L. Rocchigiani, Isr. J. Chem. 2015, 55, 134 - 149; d) L. Liu, B. Lukose, P. Jaque and B. Ensing, Green Energy Environ. 2019, 4, 20-28.

[15] a) G. Skara, F. De Vleeschouwer, P. Geerlings, F. De Proft and B. Pinter, Sci. Rep. 2017, 7, 16024; b) J. Daru, I. Bakó, A. Stirling and I. Pápai, ACS Catal. 2019, 9, 6049 - 6057; c) S. Grimme, H. Kruse, L. Goerigk and G. Erker, Angew. Chem., Int. Ed. 2010, 49, 1402 - 1405; d) D. Yepes, P. Jaque and I. Fernández, Chem. Eur. J., 2016, 22, 18801 - 18809; d) L. Liu, L. L. Cao, Y. Shao, G. Ménard and D. W. Stephan, Chem, 2017, 3, 259 - 267; e) H. B. Hamilton and D. F. Wass, Chem, 2017, 3, 198 - 210; f) T. A. Rokob, I. Bakó, A. Stirling, A. Hamza and I. Pápai, J. Am. Chem. Soc. 2013, 135, 4425 - 4437; g) G. Bistoni, A. A. Auer and F. Neese, Chem. Eur. J. 2017, 23, $865-873$.

[16] a) R. M. Bullock and G. M. Chambers, Phil. Trans. R. Soc. A, 2017, 375, 20170002; b) M. K. Karunanan and N. P. Mankad, ACS Catal. 2017, 7, 6110 - 6119; c) E. R. M. Habraken, A. R. Jupp, M. B. Brands, M. Nieger, A. W. Ehlers and J. C. Slootweg, J. Inorg. Chem. 2019, 2436 2442.

[17] a) N. P. Mankad, Chem. Commun. 2018, 54, 1291 - 1302; b) I. G. Powers and C. ACS Catal. 2017, 7, 936 - 958; c) R. C. Cammarota, L. J. Clouston and C. C. Lu, Coord. Chem. Rev. 2017, 334, 100 - 111; d) J. Berry and C. Lu, Inorg. Chem. 2017, 56, 7577 - 7581; (e) L. H. Gade, Angew. Chem. Int. Ed. 2000, 39, 2658 - 2678; e) N. P. Mankad, Chem. Eur. J. 2016, 22, 5822 5829.

[18] T. A. Rokob, A. Hamza, A. Stirling and I. Pápai, J. Am. Chem. Soc. 2009, 131, 2029 - 2036.

[19] F.-G. Fontaine and D. W. Stephan, Philos. Trans. R. Soc. A, 2017, 375, 20170004.

[20] a) T. Mahdi and D. W. Stephan, J. Am. Chem. Soc. 2014, 136, 15809 - 15812; b) D. J. Scott, M. J. Fuchter and A. E. Ashley, J. Am. Chem. Soc. 2014, 136, 15813 - 15816; c) M. A. Légaré, E. Rochette, J. Légaré Lavergne, N. Bouchard and F. G. Fontaine, Chem. Commun. 2016, 52, $5387-5390$.

[21] J. Légaré Lavergne, A. Jayaraman, L. C. Misal Castro, E. Rochette and F.-G. Fontaine, J. Am. Chem. Soc. 2017, 139, 14714 - 14723.

[22] M. V. Mane and K. Vanka, ChemCatChem, 2017, 9, 3013 - 3022.

[23] See for example: a) M. K. Karunananda, S. R. Parmelee, G. W. Waldhart and N. P. Mankad, Organometallics, 2015, 34, 3857 - 3864; b) L.-J. Cheng and N. P. Mankad, J. Am. Chem. Soc. 2019, 141, 3710 - 3716; c) T. J. Mazzacano, N. J. Leon, G. W. Waldhart and N. P. Mankad, Dalton Trans. 2017, 46, 5518 - 5521; d) I. M. Riddlestone, N. A. Rajabi, J. P. Lowe, M. F. Mahon, S. A. Macgregor and M. K. Whittlesey, J. Am. Chem. Soc. 2016, 138, 11081 - 11084; e) K. M. Gramigna, D. A. Dickie, B. M. Foxman and C. M. Thomas, ACS Catalysis, 2019, 9, 3153-3164; f) J. Coombs, D. Perry, D.-H. Kwon, C. M. Thomas and D. E. Ess, Organometallics, 2018, 37, 4195 - 4203; g) A. M. Baranger and R. G. Bergman, J. Am. Chem. Soc. 1994, 116, 3822 - 3835; h) C. M. Thomas, J. W. Napoline, G. T. Rowe and B. M. Foxman, Chem. Commun. 2010, 46, $5790-5792$.

[24] J. Bauer, H. Braunschweig and R. D. Dewhurst, Chem. Rev. 2012, 112, 4329 - 4346.

[25] M. Marín, J. J. Moreno, M. M. Alcaide, E. Álvarez, J. López-Serrano, J. Campos, M. C. Nicasio and E. Carmona, J. Organomet. Chem. 2019, 896, 120 - 128.

[26] M. F. Espada, J. Campos, J. López-Serrano, M. L. Poveda and E. Carmona, Angew. Chem., Int. Ed. 2015, 54, 15379 - 15384. 
[27] L. X. Dang, G. K. Schenter, T.-M. Chang, S. M. Kathmann and T. Autrey, J. Phys. Chem. Lett. 2012, 3, 3312- 3319 .

[28] N. Hidalgo, S. Bajo, J. J. Moreno, C. Navarro-Gilabert, B. Mercado, and J. Campos, Dalton Trans. 2019, 48, 9127 - 9138.

[29] a) H. Braunschweig, K. Radacki and K. Schwab, Chem. Commun. 2010, 46, 913 - 915; b) J. Bauer, H. Braunschweig, P. Brenner, K. Kraft, K. Radacki and K. Schwab, Chem. - Eur. J. 2010, 16, 11985 - 11992; c) J. Bauer, H. Braunschweig, A. Damme and K. Radacki, Angew. Chem., Int. Ed. 2012, 51, 10030 - 10033; d) M. Ma, A. Sidiropoulos, L. Ralte, A. Stasch and C. Jones, Chem. Commun. 2013, 49, 48 - 50; e) H. Braunschweig, R. D. Dewhurst, F. Hupp and C. Schneider, Chem. Commun. 2014, 50, 15685 - 15688; f) B. R. Barnett, C. E. Moore, P. Chandrasekaran, S. Sproules, A. L. Rheingold, S. DeBeerde and J. S. Figueroa, Chem. Sci., 2015, $6,7169-7178$.

[30] A. V. Marenich, C. J. Cramer and D. G. Truhlar, J. Phys. Chem. B 2009, 113, 6378 - 6396.

[31] R. G. Goel and R. C. Srivastava, Can. J. Chem. 1983, 61, 1352 - 1359.

[32] R. G. Goel, W. O. Ogiri and R. C. Srivastava, Organometallics, 1982, 1, 819 - 824.

[33] a) C. González-Arellano, A. Corma, M. Iglesias and F. Sánchez, Chem. Commun. 2005, 3451 - 3453; b) A. Comas-Vives and G. Ujaque, J. Am. Chem. Soc. 2013, 135, 1295 - 1305.

[34] a) E. Y. Tsui, P. Muller and J. P. Sadighi, Angew. Chem., Int. Ed. 2008, 47, 8937 - 8940; b) A. Escalle, G. Mora, F. Gagosz, N. Mezailles, X. F Le Goff, Y. Jean and P. Le Floch, Inorg. Chem. 2009, 48, $8415-8422$; c) R. J. Harris and R. A. Widenhoefer, Angew. Chem., Int. Ed. 2014, 53, $9369-9369$.

[35] H. Schmidbaurab and A. Schiera, Chem. Soc. Rev. 2012, 41, 370 - 412.

[36] N. Phillips, T. Dodson, R. Tirfoin, J. I. Bates and S. Aldridge, Chem. -Eur. J. 2014, 20, 16721 -16731 .

[37] S. Tussing, L. Greb, S. Tamke, B. Schirmer, C. Muhle-Goll, B. Luy and J. Paradies, Chem. -Eur. J. 2015, 21, 8056 - 8059.

[38] A. J. Esswein, A. S. Veige, P. M. B. Piccoli, A. J. Schultz and D. G. Nocera, Organometallics, 2008, 27, $1073-1083$.

[39] Y. Zhang, M. K. Karunananda, H.-C. Yu, K. J. Clark, W. Williams, N. P. Mankad and D. H. Ess, ACS Catal. 2019, 9, 2657 - 2663.

[40] Computational studies at the $\omega \mathrm{B} 97 \mathrm{xD} / 6-31 \mathrm{~g}(\mathrm{~d}, \mathrm{p})+\mathrm{SDD}$ level. Dispersion effects are included in the functional (D2 version of empirical dispersion by Grimme). Bulk solvent effects accounted by the SMD model (benzene and dichloromethane). Energies reported in the text are free energies with Truhlars's anharmonic corrections. The calculations have been performed with the Gaussian09 package. Gaussian 09, Revision B.01. Gaussian, Inc., Wallingford CT, 2010. See the Suplementary information for further details.

[41] Alternatively (see the Supporting information), the cis-Pt(II) dihydride forms a dimer with the $\mathrm{Au}$ fragment, $[\mathrm{Au}](\mu-\mathrm{H})_{2}[\mathrm{Pt}]$, that can evolve to two monometallic hydrides. Whereas formation of the bridging complex is easy $\left(\Delta G^{0}=20.0 \mathrm{kcal} \cdot \mathrm{mol}^{-1}\right)$, its transformation to the following intermediate featuring a dihydrogen bond, $[\mathrm{Au}]-\mathrm{H} \cdots \mathrm{H}-[\mathrm{Pt}](\mathbf{A})$, has an overall barrier $\Delta G^{\ddagger}=30.7 \mathrm{kcal} \cdot \mathrm{mol}^{-1}$. 
[42] The calculations yield a geometry for $\mathbf{4 a}$ with a different conformation of the terphenyl phosphine that is $9.9 \mathrm{kcal} \cdot \mathrm{mol}^{-1}$ above than the most stable conformation used as the origin of energies. See M. Marín, J. J. Moreno, C. Navarro-Gilabert, E. Álvarez, C. Maya, R. Peloso, M. C. Nicasio, E. Carmona, Chem. Eur. J. 2019, 25, 260 - 272.

[43] R. F. W. Bader, Atoms in Molecules: A Quantum Theory; Oxford University Press: Oxford, UK, 1995.

[44] L. Könczöl, E. Eszter Makkos, D. Bourissou and S. Szieberth, Angew. Chem. Int. Ed. 2012, $51,9521-9524$.

[45] a) N. J. Gunsalus, S. H. Park, B. G. Hashiguchi, A. Koppaka, S. J. Smith, D. H. Ess and R. A. Periana, Organometallics 2019, 38, 2319 - 2322; b) S. Das, S. Mondal and S. K. Pati, Chem. Eur. J. 2018, 24, 2575 - 2579.

[46] We considered the role of $\mathrm{NTf}_{2}{ }^{-}$as a base in $\mathrm{H}_{2}$ activation. As expected, $\mathrm{H}-\mathrm{H}$ cleavage between $\mathbf{1 a}\left(\mathrm{H}_{2}\right)^{+}$and $\mathrm{NTf}_{2}{ }^{-}$was found to occur through a high energy TS lying $30.0 \mathrm{kcal} \cdot \mathrm{mol}^{-1}$ above the reactants, $\mathbf{4 a}+\mathrm{H}_{2}$ (see Figure $\mathrm{S} 4$ ).

[47] J. J. Cabrera-Trujillo and I. Fernández, Inorg. Chem. 2019, 58, 7828 - 7836.

[48] While a correct analysis of KIEs requires full statistical mechanical treatment, it has been showed that at least for some cases KIEs and EIEs are controlled by ZPE differences: a) D. G. Churchill, K. E. Janak, J. S. Wittenberg and G. Parkin, J. Am. Chem. Soc. 2003, 125, $1403-1420$; b) F. Abu-Hasanayn, K. Krogh-Jespersen and A. S. Goldman, J. Am. Chem. Soc. 1993, 115, 8019 - 8023; c) F. Abu-Hasanayn, A. S. Goldman and K. Krogh-Jespersen, J. Phys. Chem. 1993, 97, 5890 - 5896; d) G. Parkin, Acc. Chem. Res. 2009, 42, 315 - 325; e) B. R. Bender, G. J. Kubas, L. H. Jones, B. I. Swanson, J. Eckert, K. B. Capps and C. D. Hoff, J. Am. Chem. Soc. 1997, 119, $9179-9190$.

[49] Focusing on $Z P E$ changes, the bond strength $(D)$ can be approximated as: $D=E-1 / 2 h v$, where $E$ is the potential energy and $v$ is the vibrational frequency, which equals $(1 / 2 \pi) \sqrt{k / \mu}$. In this equation $k$ is the force constant and $\mu(H / D)$ is the reduced mass of the $\mathrm{E}-\mathrm{H}(\mathrm{D})$ bond. It can be assumed that $E$ and $k$ do not change in each set of isotopomers (e.g. $\mathrm{H}_{2} \vee \mathrm{D}_{2}$ ). Therefore, the difference in zero-point energy for a pair of isotopomers (reactants, products or TSs) is: $\triangle Z P E \sim D(D)-D(H)=1 / 2 h[v(D)-v(H)]$. i.e., the isotope effect depends on the differences in the vibrational frequencies of the isotopomers. The previous equations can also be written in terms force constants and reduced mass as: $\triangle Z P E \propto k^{1 / 2}\left[\mu(D)^{-1 / 2}-\mu(H)^{-1 / 2}\right]$. Thus, higher force constants at the TS than at the reactants are major contributors to an inverse primary KIE. In our case the difference in zero-point energy between the TS and the reactants can also be written in terms of vibrational frequencies: $\triangle \triangle Z P E \propto 1 / 2 h\left[\left\{\sum v_{D}^{T S}-v^{R}(D-D)\right\}-\left\{\sum v_{H}^{T S}-\right.\right.$ $\left.v^{R}(H-H\}\right]$, where $\sum v^{T S}$ represent the collective isotopically sensitive vibrational modes at the TS.

[50] a) T.-Y. Cheng and R. M. Bullock, J. Am. Chem. Soc. 1999, 121, $3150-3155$; b) H. C. Lo, A. Haskel, M. Kapon and E. Keinan, J. Am. Chem. Soc. 2002, 124, 3226 - 3228.

[51] J. Bigeleisen, J. Pure. Appl. Chem. 1964, 8, 217 - 223.

[52] M. Gómez-Gállego and M. A. Sierra, Chem. Rev. 2011, 111, 4857 -4963.

[53] For some selected examples see: a) R. A. Periana and R. G. Bergman, J. Am. Chem. Soc. 1986, 108, $7332-7346$ and reference 14 therein; b) D. G. Churchill, K. E. Janak, J. S. Wittenberg and G. Parkin, J. Am. Chem. Soc. 2003, 125, 1403 - 1420; c) T. O. Northcutt, D. D. Wick, A. J. Vetter and W. D. Jones, J. Am. Chem. Soc. 2001, 123, $7257-7270$. 
[54] L. Ortega-Moreno, M. Fernández-Espada, J. J. Moreno, C. Navarro, J. Campos, S. Conejero, J. López-Serrano, C. Maya, R. Peloso and E. Carmona, Polyhedron, 2016, 116, 170 - 181.

[55] R. Uson, A. Laguna, M. Laguna, D. A. Briggs, H. H. Murray and J. P. Fackler, Inorg. Synth. 2007, 26, $85-91$.

[56] H. R. C. Jaw, W. R. Mason, Inorg. Chem. 1989, 28, 4370 - 4373.

[57] Gaussian 09, Revision B.01, M. J. Frisch, G. W. Trucks, H. B. Schlegel, G. E. Scuseria, M. A. Robb, J. R. Cheeseman, G. Scalmani, V. Barone, B. Mennucci, G. A. Petersson, H. Nakatsuji, M. Caricato, X. Li, H. P. Hratchian, A. F. Izmaylov, J. Bloino, G. Zheng, J. L. Sonnenberg, M. Hada, M. Ehara, K. Toyota, R. Fukuda, J. Hasegawa, M. Ishida, T. Nakajima, Y. Honda, O. Kitao, H. Nakai, T. Vreven, J. A. Montgomery, Jr., J. E. Peralta, F. Ogliaro, M. Bearpark, J. J. Heyd, E. Brothers, K. N. Kudin, V. N. Staroverov, T. Keith, R. Kobayashi, J. Normand, K. Raghavachari, A. Rendell, J. C. Burant, S. S. Iyengar, J. Tomasi, M. Cossi, N. Rega, J. M. Millam, M. Klene, J. E. Knox, J. B. Cross, V. Bakken, C. Adamo, J. Jaramillo, R. Gomperts, R. E. Stratmann, O. Yazyev, A. J. Austin, R. Cammi, C. Pomelli, J. W. Ochterski, R. L. Martin, K. Morokuma, V. G. Zakrzewski, G. A. Voth, P. Salvador, J. J. Dannenberg, S. Dapprich, A. D. Daniels, O. Farkas, J. B. Foresman, J. V. Ortiz, J. Cioslowski, and D. J. Fox, Gaussian, Inc., Wallingford CT, 2010.

[58] J.-D. Chai and M. Head-Gordon, Phys. Chem. Chem. Phys. 2008, 10, 6615- 6620.

[59] S. Grimme, J. Comp. Chem. 2006, 27, 1787-1799.

[60] a) R. Ditchfield, W. J. Hehre and J. A. Pople. J. Chem. Phys. 1971, 54, 724 - 728; b) W. J. Hehre, R. Ditchfield and J. A. Pople. J. Chem. Phys. 1972, 56, 2257 - 2261; c) P. C. Hariharan and J. A. Pople. Theor. Chim. Acta 1973, 28, 213 - 222; d) M. M. Francl, W. J. Pietro, W. J. Hehre, J. S. Binkley, M. S. Gordon, D. J. DeFrees and J. A. Pople. J. Chem. Phys. 1982, 77, 3654 -3665 .

[61] D. Andrae, U. Haeussermann, M. Dolg, H. Stoll and H. Preuss. Theor. Chim. Acta 1990, 77, $123-141$.

[62] A. V. Marenich, C. J. Cramer and D. G. Truhlar. J. Phys. Chem. B 2009, 113, $6378-6396$.

[63] R. F. Ribeiro, A. V. Marenich, C. J. Cramer and D. G. Truhlar, J. Phys. Chem. B 2011, 115, $14556-14562$

[64] I. Funes-Ardoiz, R. S. Paton, (2016). Goodvibes: Goodvibes 2.0.2 http://doi.org/10.5281/zenodo.595246

[65] NBO 6.0. E. D. Glendening, J. K. Badenhoop, A. E. Reed, J. E. Carpenter, J. A. Bohmann, C. M. Morales, C. R. Landis, and F. Weinhold (Theoretical Chemistry Institute, University of Wisconsin, Madison, WI, 2013); http://nbo6.chem.wisc.edu/

[66] R. F. W. Bader, Atom in Molecules: A Quantum Theory; Oxford University Press: Oxford, UK, 1995.

[67] a) Multiwfn: A multifunctional wavefunction analyser. T. Lu, F. Chen, J. Comput. Chem., 2012, 33, 580-592; b) Multiwfn 3.6, http://sobereva.com/multiwfn/

[68] CYLview, 1.0b; Legault, C. Y., Université de Sherbrooke, 2009 (http://www.cylview.org) 